\title{
Synthesis, solid-state structures, solution behaviour and catalysis studies of nickel complexes
} of bis(benzimidazolin-2-ylidene)pyridine pincer ligands

Karen D. M. MaGee, ${ }^{\mathrm{A}}$ Guy Travers, ${ }^{\mathrm{A}}$ Brian W. Skelton, ${ }^{\mathrm{B}}$ Massimilliano Massi, ${ }^{\mathrm{A}}$ Alan D. Payne, ${ }^{\mathrm{A}}$ and David H. Brown ${ }^{\mathrm{A}, \mathrm{C}, \mathrm{D}}$

A Department of Chemistry, Curtin University, GPO Box U1987, Perth WA 6845, Australia

${ }^{B}$ Centre for Microscopy, Characterisation and Analysis, The University of Western Australia, 35

Stirling Highway, Crawley, WA 6009, Australia

${ }^{\mathrm{C}}$ School of Biomedical, Biomolecular and Chemical Sciences, The University of Western Australia, 35 Stirling Hwy, Crawley, WA 6009, Australia

D Corresponding author. Email: d.h.brown@curtin.edu.au

\begin{abstract}
$N$-Heterocyclic carbene-nickel complexes with five- and four-coordinate geometries [(CNC) $\left.\mathrm{NiBr}_{2}\right]$ and $[(\mathrm{CNC}) \mathrm{NiBr}] \mathrm{X}\left(\mathrm{X}=\mathrm{PF}_{6}\right.$ or $\left.\mathrm{BPh}_{4}\right)$ have been prepared with the pincer ligands 2,6-bis $(N$ octylbenzimidazolin-2-ylidene)pyridine and 2,6-bis( $N$-butyl-5,6-dimethoxybenzimidazolin-2ylidene)pyridine. The addition of the $n$-octyl substituent significantly extends the solubility of the complexes and has allowed UV-vis solution studies of the complexes in dichloromethane and methanol. The four- and five- coordinate species exist in equilibrium in solution and this equilibria has been explored by UV-vis studies. The complexes have also been characterised by NMR studies, and single crystal $\mathrm{X}$-ray diffraction studies have been performed on $\left[(\mathrm{CNC}) \mathrm{NiBr}_{2}\right][$ where $\mathrm{CNC}=$ 2,6-bis $(N$-octylbenzimidazolin-2-ylidene)pyridine $]$ and $[(\mathrm{CNC}) \mathrm{NiBr}] \mathrm{BPh}_{4}$ [where $\mathrm{CNC}=2$,6$\operatorname{bis}(N$-butyl-5,6-dimethoxybenzimidazolin-2-ylidene)pyridine] .
\end{abstract}

Dedicated to Professor Allan H. White on the occasion of his 75th birthday. 


\section{Introduction}

Metal complexes of 'pincer' ligands bearing $N$-heterocyclic carbenes (NHCs) have been studied extensively, involving a range of additional donor types. ${ }^{[1-3]}$ Within this class of compounds NHC 'pincer' ligands with a pyridyl core are common (e.g. 1). Although there is now an extensive variety of different NHC structural motifs, the pyridyl-core CNC pincer has predominantly been explored with imidazole-derived NHCs. Metal complexes of 2,6-bis(imidazol-2-ylidene)pyridine type ligands cover the majority of the d-block elements, with significant interest in catalysis applications. ${ }^{[1,2,4-8]}$ By comparison, complexes of the benzimidazole-based 2,6-bis(benzimidazolin2-ylidene)pyridine ligand system have only been reported with $\mathrm{Pd}, \mathrm{Ag}$, Os and recently $\mathrm{Ni}^{[4,9-14]}$

In our recent exploration of nickel complexes of the 2,6-bis(benzimidazolin-2ylidene)pyridine ligand system we identified the formation of the five-coordinate [(CNC)NiX $\left.\mathrm{N}_{2}\right]$ complexes $2(\mathrm{X}=\mathrm{Cl}, \mathrm{Br}),{ }^{[13]}$ an unusual coordination geometry for this CNC ligand system. Other studies of nickel complexes with 2,6-bis(imidazol-2-ylidene)pyridine ligands have predominantly identified only four-coordinate $[(\mathrm{CNC}) \mathrm{NiX}]^{+}$geometries, ${ }^{[7,15-17]}$ with one example of a sixcoordinate nickel complex. ${ }^{[17]}$ The five-coordinate complexes $\mathbf{2}$ displayed surprisingly low solubility in a range of organic solvents, and our studies suggested dissolution of these purple $\left[(\mathrm{CNC}) \mathrm{NiX}_{2}\right]$ complexes resulted in formation of yellow solutions containing $[(\mathrm{CNC}) \mathrm{NiX}]^{+}$cations $3(\mathrm{X}=\mathrm{Cl}, \mathrm{Br}){ }^{[13]}$

In this paper we report our continued exploration of these nickel complexes bearing 2,6bis(benzimidazolin-2-ylidene)pyridine ligands, including catalysis studies in Kumada coupling reactions. Incorporation of octyl-substituents has allowed us to explore the solution behaviour of these complexes in solvents other than highly polar solvents such as methanol. In addition we have explored the incorporation of methoxy groups to the periphery of the benzimidazole moiety, since incorporation of these groups to the 5,6-positions should not influence the coordination environment based on sterics, but may influence the electronic properties of the carbene donor 
atom. A number of studies have incorporated methoxy groups onto benzimidazolin-2-ylidenes in an effort to explore the influence they have on metal complexation. ${ }^{[18-23]}$

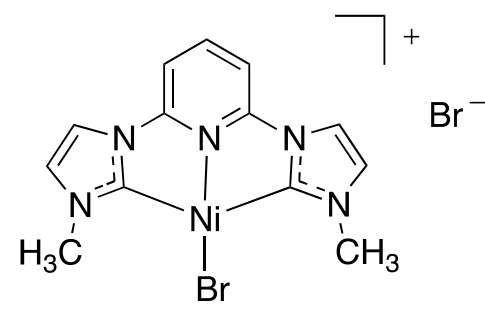

$1 \cdot \mathrm{Br}$

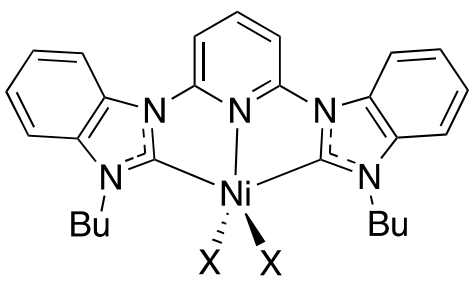

2

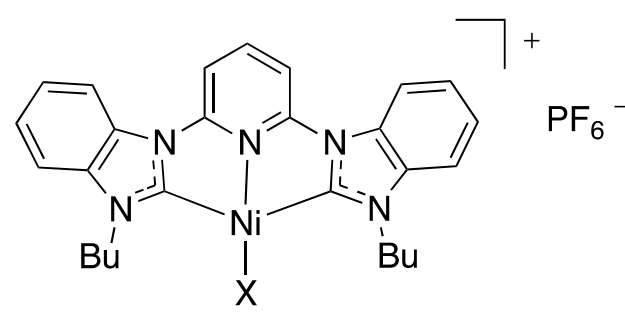

$3 \cdot \mathrm{PF}_{6}$

Fig. 1.

\section{Results and Discussion}

The syntheses reported here are derived from the previously reported procedures for the synthesis of $2(\mathrm{X}=\mathrm{Br}), 3 \cdot \mathrm{PF}_{6}(\mathrm{X}=\mathrm{Br})$ and the bis(benzimidazolium) dibromide salt used as the ligand precursor. ${ }^{[10,13]}$ Treatment of 5,6-dimethoxybenzimidazole ${ }^{[24]}$ with sodium hydride and then reaction of the resulting benzimidazolate anion with 2,6-dichloropyridine in $\mathrm{DMF}$ at $70^{\circ} \mathrm{C}$ for 24 hours and then $140{ }^{\circ} \mathrm{C}$ for a further 24 hours affords 1,3-bis(5,6-dimethoxybenzimidazol-1-yl)yridine (4) in good yield (Scheme 1). Alkylation of 4 with a large excess of 1-bromobutane affords the 
bis(benzimidazolium) salt $\mathbf{5} \cdot 2 \mathrm{Br}$. A solution of $\mathbf{5} \cdot 2 \mathrm{Br}$ and nickel acetate tetrahydrate in DMF was heated from room temperature to $c a .110{ }^{\circ} \mathrm{C}$ over the course of $c a .10$ minutes, and then immediately allowed to cool, which resulted in the formation of the five-coordinate nickel complex 6 as a purple precipitate, which could be further purified by recrystallisation from nitromethane. Treatment of a mixture $\mathbf{6}$ and potassium hexafluorophosphate in methanol affords the fourcoordinate complex salt $\mathbf{7} \cdot \mathrm{PF}_{6}$ as an orange powder in high yield (Scheme 1). Attempts to grow single crystals of either $\mathbf{6}$ or $\mathbf{7} \cdot \mathrm{PF}_{6}$ proved difficult, routinely affording extremely fine needles that were not suitable for single crystal X-ray studies. Such behaviour was also observed for the previously studied non-methoxy analogues $2(\mathrm{X}=\mathrm{Br})$ and $\mathbf{3} \cdot \mathrm{PF}_{6}(\mathrm{X}=\mathrm{Br}) .{ }^{[13]}$ The salt $\mathbf{7} \cdot \mathrm{BPh}_{4}$ was prepared similarly to that of $\mathbf{7} \cdot \mathrm{PF}_{6}$, using sodium tetraphenylborate instead of potassium hexafluorophosphate. Recrystallisation of the tetraphenylborate salt $\mathbf{7} \cdot \mathrm{BPh}_{4}$ afforded single crystals that were suitable for X-ray studies (see Solid-state studies). Dissolution of $7 \cdot \mathrm{PF}_{6}$ in methanol or dichloromethane affords bright yellow solutions. In the case of $\mathbf{6}$ solutions in methanol are bright yellow whereas solutions in dichloromethane are yellow to orange, depending on concentration. 


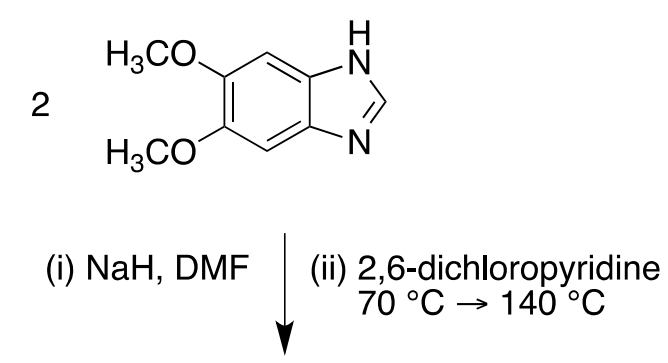<smiles>COc1cc2ncn(-c3cccc(-n4cnc5cc(OC)c(OC)cc54)n3)c2cc1OC</smiles>

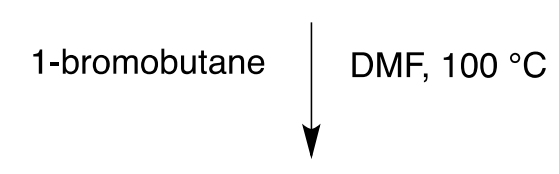<smiles>COc1cc2c3cc(OC)c(OC)cc3n(-c3cccc(-n4c[n+](C(Br)(Br)Br)c5ccccc54)n3)c2cc1OC</smiles>

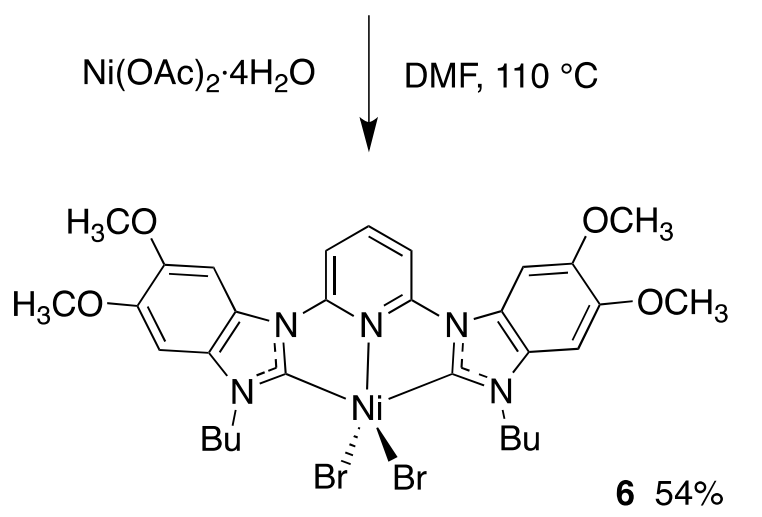

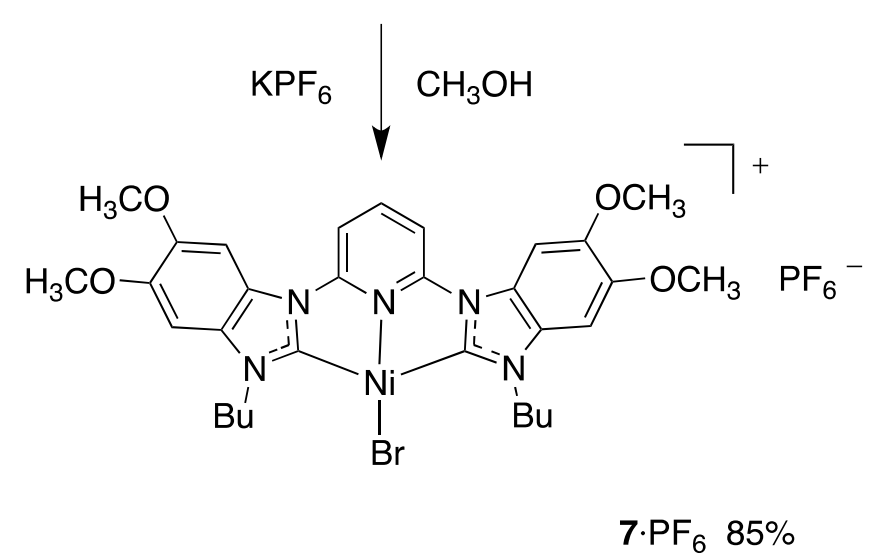

Scheme 1. Synthesis of the pyridyl-bis(dimethyoxybenzimidazolium) salt $5 \cdot 2 \mathrm{Br}$ and the bis(dimethyloxybenzimidazolin-2-ylidene)pyridine nickel complexes 6 and $7 \cdot \mathrm{PF}_{6}$. 
Our previous solution studies of the five-coordinate complex $2(\mathrm{X}=\mathrm{Br})$ were restricted to polar solvents due to the insoluble nature of 2 . In an effort to improve the solubility of such systems, and to further explore the solution behaviour of these complexes, we synthesised the $n$ octyl-substituted bis(benzimidazolium) salt $\mathbf{8} \cdot 2 \mathrm{Br}$ and the five- and four-coordinate complexes 9 and $\mathbf{1 0} \cdot \mathrm{PF}_{6}$ in good yields using procedures similar to those described above (Fig. 2). As with 2 (X $=\mathrm{Br})$ and $\mathbf{3} \cdot \mathrm{PF}_{6}(\mathrm{X}=\mathrm{Br})$, attempts to grow crystals of $\mathbf{9}$ and $\mathbf{1 0} \cdot \mathrm{PF}_{6}$ invariably afforded extremely fine needles, however we were fortunate that when using THF and methanol as recrystallisation solvents dark purple crystals of $\mathbf{9}$, suitable for X-ray studies, were isolated (see Solid-state studies). The addition of the octyl-substituents significantly improved the solubility of the complexes, particularly the five-coordinate complex 9 that proved to be soluble in chlorinated solvents such as dichloromethane, affording purple/brown coloured solutions. This contrasts with the butyl substituted complex $2(\mathrm{X}=\mathrm{Br})$ which only displayed appreciable solubility in more polar solvents such as methanol, and upon dissolution (of the purple solid) afforded yellow solutions. 

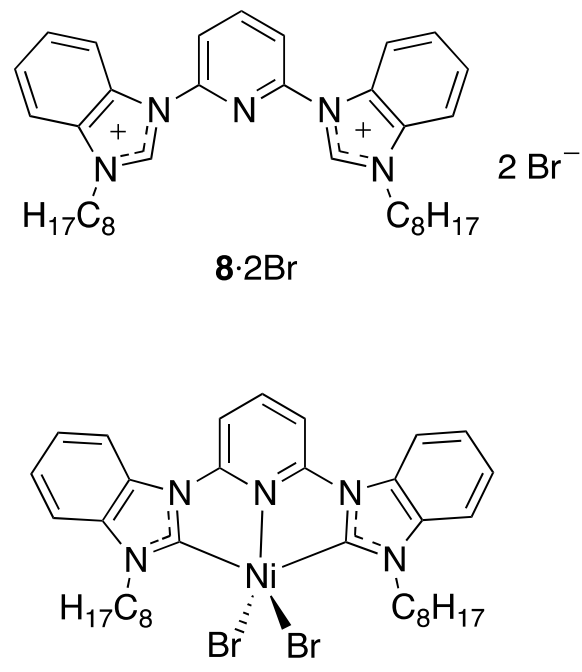

9

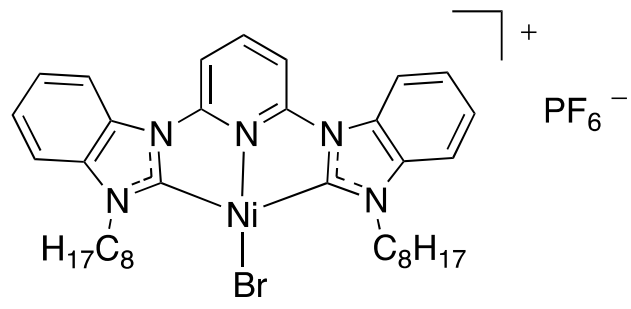

$10 \cdot \mathrm{PF}_{6}$

Fig. 2. n-Octyl-substituted compounds reported in this paper.

All compounds were characterised by ${ }^{1} \mathrm{H}$ and ${ }^{13} \mathrm{C}$ NMR studies. The ${ }^{13} \mathrm{C}$ NMR spectra of the nickel complexes were obtained using relatively concentrated solutions of the complexes. Solutions were prepared using chloroform- $d$ (with a drop of $d_{3}$-methanol) for the five-coordinate complexes 6 (orange in colour) and 9 (dark brown/purple in colour), and chloroform- $d$ (with $d_{6^{-}}$ dimethylsulfoxide) for the four-coordinate materials $7 \cdot \mathrm{PF}_{6}$ and $\mathbf{1 0} \cdot \mathrm{PF}_{6}$. Each of the ${ }^{13} \mathrm{C} \mathrm{NMR}$ spectra displayed a relatively sharp downfield signal attributed to the carbene carbons bound to each nickel centre $\left[\delta_{\mathrm{C}} 166.4(\mathbf{6}) ; 172.0(\mathbf{9}) ; 165.6\left(\mathbf{7} \cdot \mathrm{PF}_{6}\right) ; 169.8\left(\mathbf{1 0} \cdot \mathrm{PF}_{6}\right)\right]$. However, at these concentrations the ${ }^{1} \mathrm{H}$ NMR spectra often displayed broadened signals for the solutions of the fivecoordinate complexes 6 and 9. Dilution of the solutions resulted in sharper spectra from which accurate data could be obtained. 
Table 1 summarizes selected coordination geometries for the two structures 9 and $7 \cdot \mathrm{BPh}_{4} \cdot \mathrm{Et}_{2} \mathrm{O}$.

The structure for 9 displays a distorted trigonal bipyramidal geometry around the nickel centre, with the two bromide atoms and N21 forming the horizontal plane and the carbene carbons C12 and C32 occupying the axial positions (Fig. 3). The geometry in $\mathbf{9}$ is similar to that of the crystallographically characterised chlorido complex $2(\mathrm{X}=\mathrm{Cl})^{[13]}$ and a related $\left[\left(\mathrm{CNC}^{\mathrm{P}} \mathrm{PdI}_{2}\right]\right.$ complex. ${ }^{[11]}$ The structure of 9 represents only the 3rd crystallographically characterised example of this unusual five-coordinate geometry for nickel or palladium complexes of this class of pincer ligand system. ${ }^{[1,13]}$ Group 10 metal complexes of these types of $N$-heterocyclic carbene CNC pincer ligands typically display four-coordinate planar geometries. ${ }^{[10,15-17,25]}$ Interestingly, the fivecoordinate geometries have been only observed with CNC ligands based on benzimidazolin-2ylidenes and not the more common imidazol-2-ylidenes. ${ }^{[11,13]}$

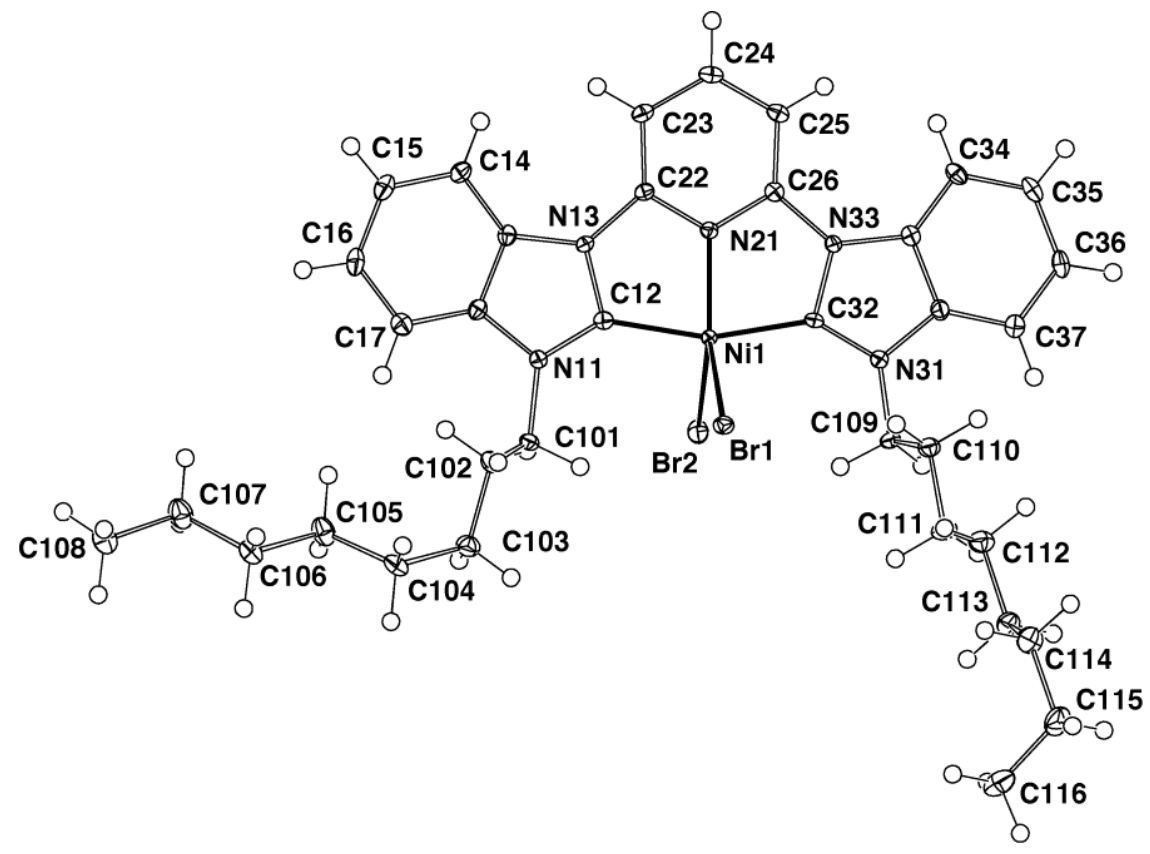

Fig. 3. Molecular structure of 9 
The cation 7 shows an essentially co-planar molecule with the exception of the pendant butyl chains and methoxy groups (Fig. 4). The most deviant atoms from the plane are C24 $(\delta 0.122(2) \AA)$ and C35 ( $\delta 0.166(2) \AA$ ). The dihedrals between the planes of the two benzimidazolin-2-ylidene groups and the pyridyl groups are 3.60(6) ${ }^{\circ}$ (between planes 1 and 2) and 5.17(6) ${ }^{\circ}$ (between planes 2 and 3). The dihedral angle between the two benzimidazolin-2-ylidene groups (planes 1 and 3) is 1.68(5) $\circ$. The unit cell containing $\mathbf{7} \cdot \mathrm{BPh}_{4}$ also includes one molecule of diethyl ether (solvent) per molecule of compound (Fig. 5). The cations are arranged in the cell as centrosymmetrically related

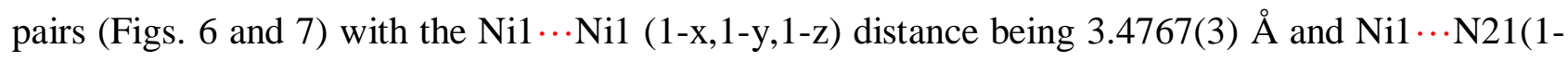
$\mathrm{x}, 1-\mathrm{y}, 1-\mathrm{z}) 3.5834(2) \AA$. The coordination geometry around the nickel centre is approximately square planar. There is no significant deflection of the bromide atom away from planarity, with a N(21)$\mathrm{Ni}(1)-\mathrm{Br}(1)$ angle of $179.54(5)^{\circ}$ and a total deviation of the bromide atom out of the $\mathrm{NC}_{2} \mathrm{Ni}$ plane of 0.019(3) $\AA$; compared to $166.68(9)^{\circ}$ and 0.528(4) $\AA$ for the non-methoxy analogue $3 \cdot \mathrm{PF}_{6}(\mathrm{X}=$ Br). ${ }^{[13]}$ The 'cavity' for the bromido ligand to occupy in the ideal square-planar geometry, as measured by the distance between the two benzimidazole bound methylene carbons $\mathrm{C} 1 \cdots \mathrm{C} 5$ is only slightly larger in the methoxy functionalised complex, at 6.594(2) $\AA$, compared to that of 6.547(6) $\AA$ for $3 \cdot \mathrm{PF}_{6}(\mathrm{X}=\mathrm{Br}) \cdot{ }^{[13]} \mathrm{A}$ comparison of the solid state structures for the cations in $\mathbf{7}$ and $\mathbf{3}(\mathrm{X}=$ $\mathrm{Br}$ ) does not reveal any obvious reasons as to why the coordination geometry around the nickel centres should vary so significantly, however the variation in their geometries appear to correlate with the observed differences in their solution behaviour. 


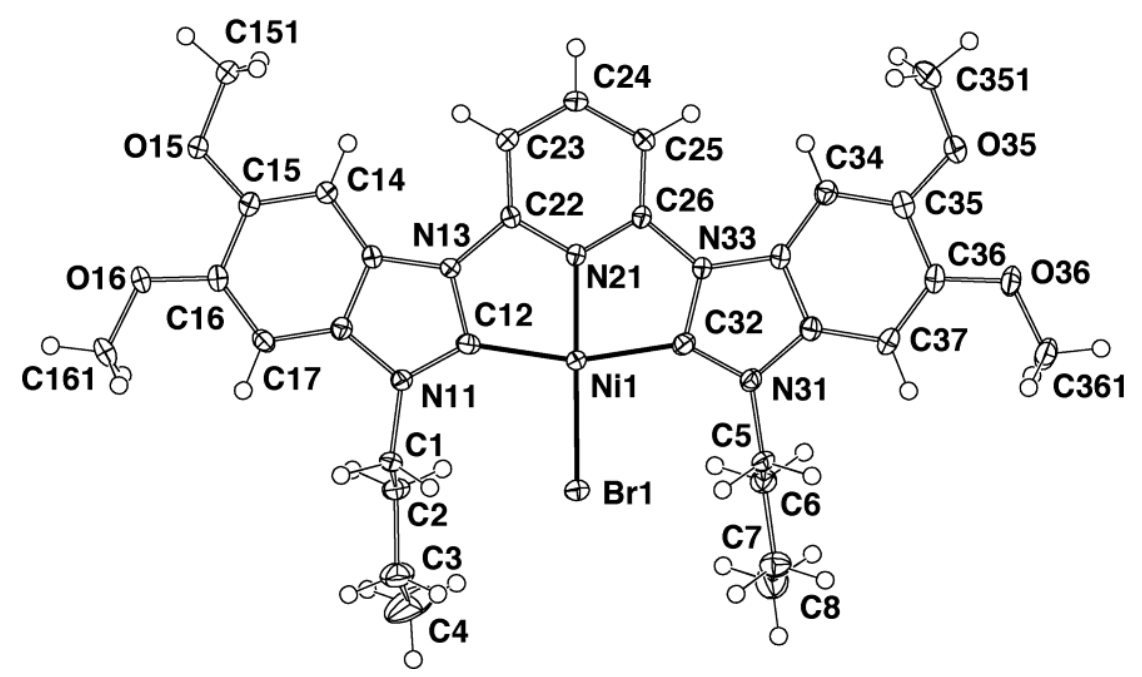

Fig. 4. Structure of cation 7 projected onto the coordination plane.

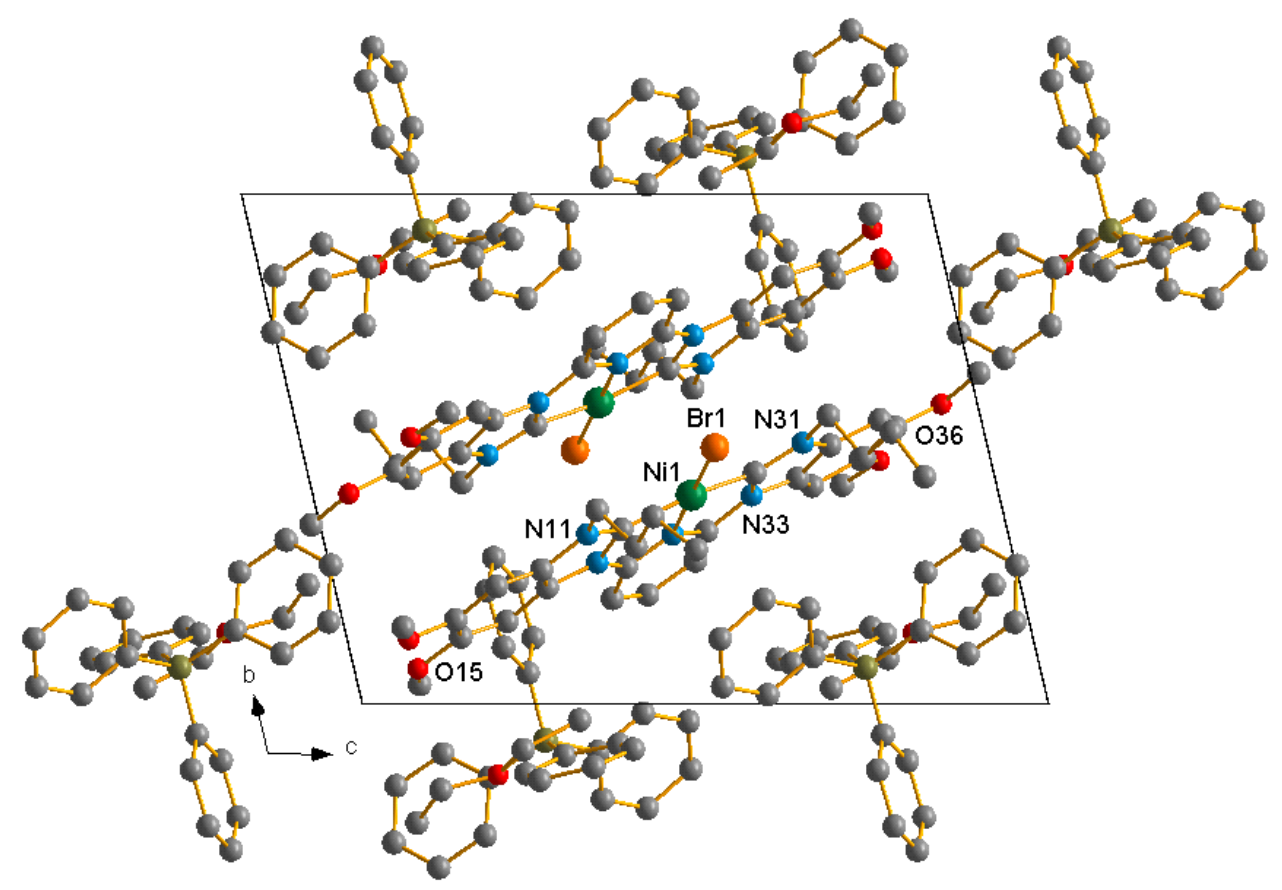

Fig. 5. Unit cell contents of 7. $\mathrm{BPh}_{4} \cdot \mathrm{Et}_{2} \mathrm{O}$ projected along the $a$ axis. 

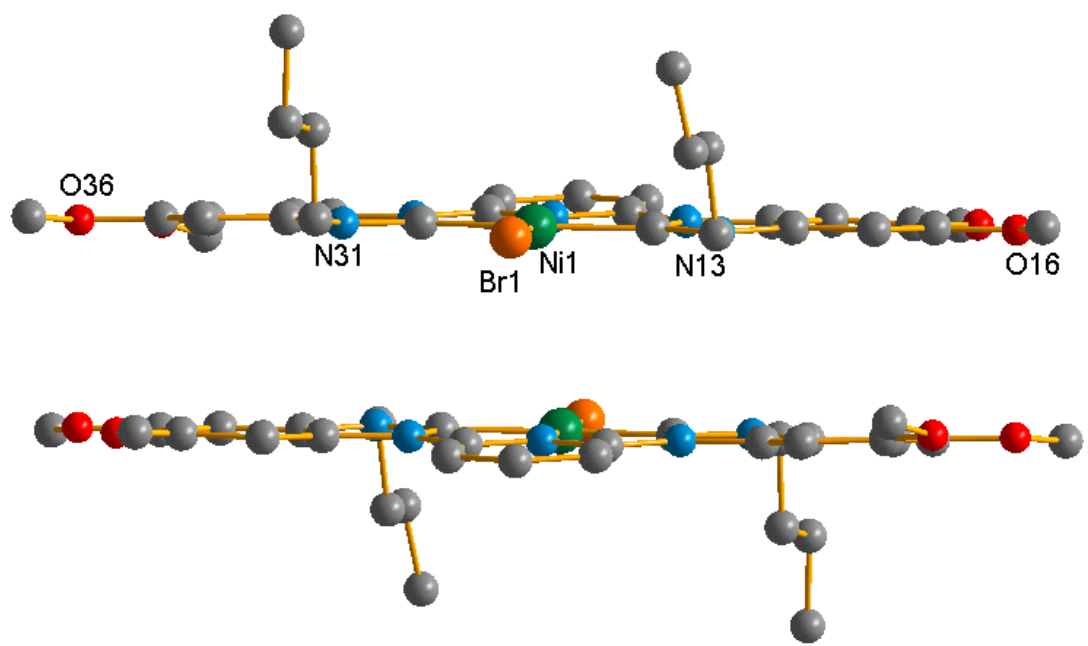

Fig. 6. A pair of centrosymmetrically related cations of 7 projected oblique to the coordination plane.

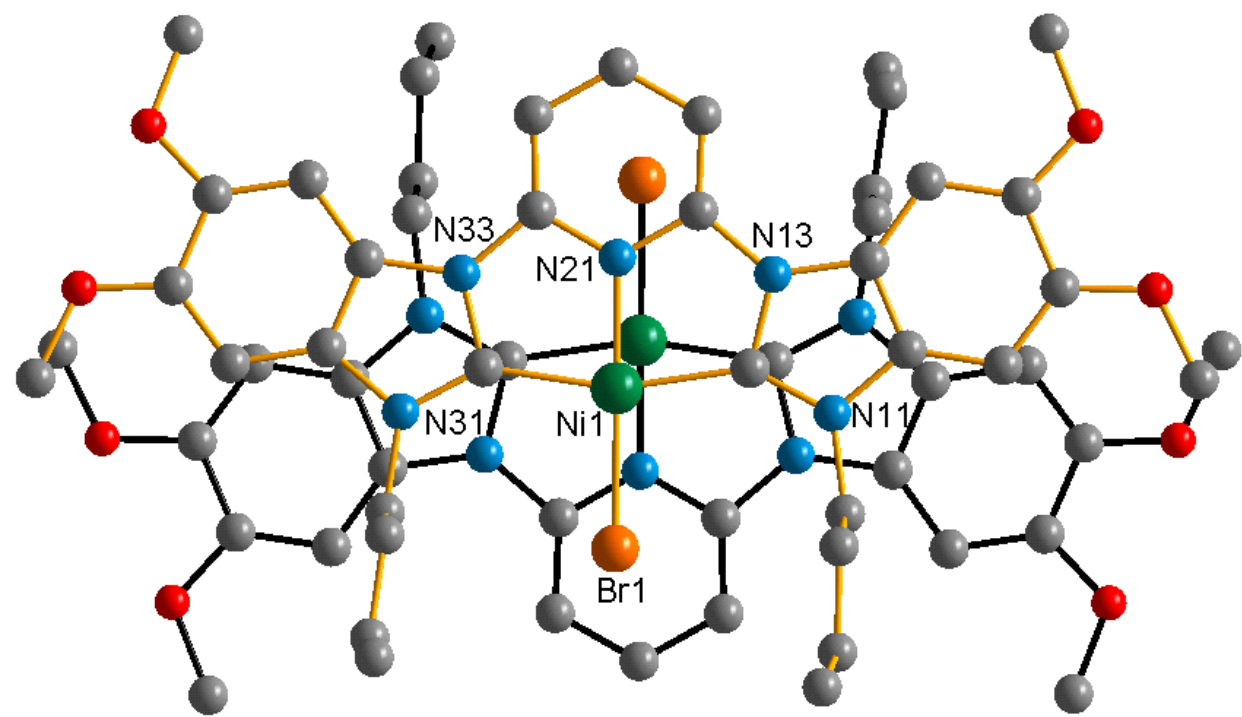

Fig. 7. A pair of centrosymmetrically related cations of 7 projected on to the coordination plane. The molecule at 1-x,1-y,1-z is shown with blackened bonds. 
Table 1. Selected bond lengths $[\AA]$ and angles $\left[{ }^{\circ}\right]$ for $\mathbf{7}$ and $\mathbf{9}$, and relevant literature examples.

\begin{tabular}{llllllll}
\hline Complex & $\mathrm{C}-\mathrm{Ni}(\AA)$ & $\mathrm{N}-\mathrm{Ni}(\AA)$ & $\mathrm{Ni}-\mathrm{X}(\AA)$ & $\mathrm{C}-\mathrm{Ni}-\mathrm{C}\left(^{\circ}\right)$ & $\mathrm{N}-\mathrm{Ni}-\mathrm{X}\left({ }^{\circ}\right)$ & $\mathrm{R} \cdots \mathrm{R}^{a}(\AA)$ & $\mathrm{NC}_{2} \mathrm{Ni} \cdots \mathrm{X}^{b}(\AA)$ \\
\hline $\mathbf{7} \cdot \mathrm{BPh}_{4}$ & $1.929(2)$, & $1.866(2)$ & $2.2989(4)$ & $162.73(8)$ & $179.54(5)$ & $6.594(2)$ & $0.019(3)$ \\
& $1.933(1)$ & & & & & & \\
$\mathbf{3} \cdot \mathrm{PF}_{6}(\mathrm{X}=$ & $1.924(4)$, & $1.866(3)$ & $2.2955(6)$ & $163.08(14)$ & $166.68(9)$ & $6.547(6)$ & $0.528(4)$ \\
$\mathrm{Br}^{[13]}$ & $1.932(4)$ & & & & & & \\
$\mathbf{9}$ & $1.894(2)$, & $1.876(2)$ & $2.5177(5)$, & $161.7(1)$ & $127.50(6)$, & $6.341(4)$ & $1.998(3)$, \\
& $1.890(2)$ & & $2.4404(4)$ & & $132.46(6)$ & & $1.797(3)$ \\
$\mathbf{2}(\mathrm{X}=\mathrm{Cl})^{[13]}$ & $1.897(6)$, & $1.871(5)$ & $2.2791(18)$, & $162.0(3)$ & $141.38(17)$, & $6.270(10)$ & $2.192(4)$, \\
& $1.900(7)$ & & $2.4324(19)$ & & $115.64(17)$ & & $1.424(6)$ \\
\hline${ }^{a}$
\end{tabular}

${ }^{a}$ The distance between the two carbon atoms, of the alkyl substituents, bound to the azolyl nitrogen. ${ }^{b}$ The distance of the halide out of the $\mathrm{NC}_{2} \mathrm{Ni}$ plane

\section{$U V$-vis studies}

In our earlier studies of the five-coordinate $\left[(\mathrm{CNC}) \mathrm{NiBr}_{2}\right] \mathbf{2}$, the low solubility of the complex in various organic solvents limited our solution studies to polar solvents such as methanol. ${ }^{[13]}$ In these studies the UV-vis spectra of solutions of $\left[(\mathrm{CNC}) \mathrm{NiBr}_{2}\right] \mathbf{2}$ in methanol were almost identical to those of the four-coordinate $\left[(\mathrm{CNC}) \mathrm{NiBr}_{\mathrm{PF}} \mathrm{P} \cdot \mathrm{PF}_{6}\right.$ in methanol, which suggested the dissolution of the five-coordinate $\left[(\mathrm{CNC}) \mathrm{NiBr}_{2}\right] \mathbf{2}$ afforded solutions of the four-coordinate cation $[(\mathrm{CNC}) \mathrm{NiBr}]^{+}{ }^{[13]}$ The improved solubility of the ocyl-substituted $\left[(\mathrm{CNC}) \mathrm{NiBr}_{2}\right] \mathbf{9}$ in chlorinated solvents compared to the butyl-analogue $2(\mathrm{X}=\mathrm{Br})$ allowed for further studies of the solution behaviour of these types of complexes.

Solutions of 9 in dichloromethane were brown/purple (Fig. 8) whereas solutions in methanol were bright yellow. The differences in solution colour are consistent with the dramatically different UV-vis spectra (Fig. 9). The spectrum for a methanol solution of 9 (Fig. 9) is very similar to that of the spectra for solutions of the four-coordinate $[(\mathrm{CNC}) \mathrm{NiBr}] \mathrm{PF}_{6} \quad \mathbf{1 0} \cdot \mathrm{PF}_{6}$ in methanol or dichloromethane (Fig. 9), which excludes the possibility that the absorption profile of 9 in methanol originates from the cationic solvato-complex with a distorted trigonal bipyramidal geometry. This data is consistent with the dissolution of $[(\mathrm{CNC}) \mathrm{NiBr}] \mathrm{PF}_{6} \mathbf{1 0} \cdot \mathrm{PF}_{6}$ in either methanol or dichloromethane resulting in solutions with the four-coordinate species $[(\mathrm{CNC}) \mathrm{NiBr}]^{+} \mathbf{1 0}$, as well as dissolution of 9 in methanol forming the same four-coordinate species. We assume that the spectra of 9 in dichloromethane (Fig. 9) is a spectrum of the five-coordinate species in solution, based on 
the stark differences in colour in solution (brown/purple for 9 in dichloromethane; bright yellow for 10 in dichloromethane) that parallels their solid state appearances (purple powders for 9; yellow powders for 10 $\mathrm{PF}_{6}$ ) (see Supporting Information).

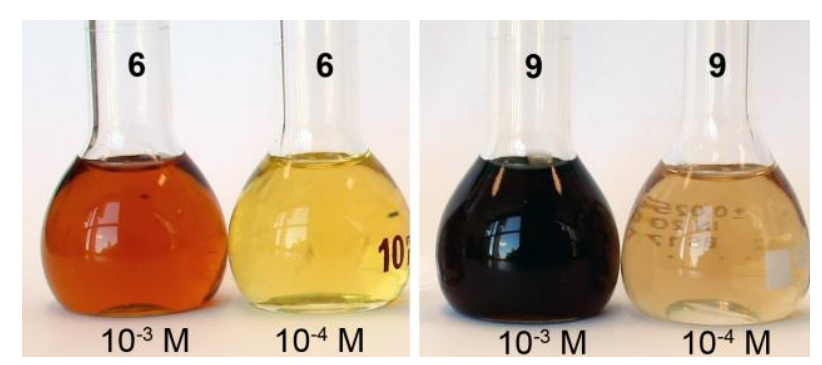

Fig. 8. Solutions of 6 and 9 in dichloromethane $\left(1 \times 10^{-3}\right.$ and $\left.1 \times 10^{-4} \mathrm{M}\right)$

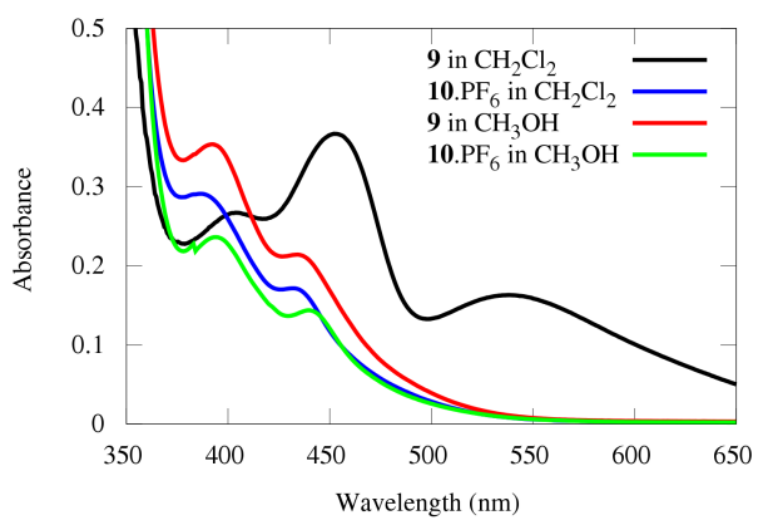

Fig. 9. UV-vis spectra of solutions of $\mathbf{9}$ and $\mathbf{1 0} \cdot \mathrm{PF}_{6}$ in methanol and dichloromethane $\left(\mathrm{ca} .10^{-4} \mathrm{M}\right)$.

The addition of tetrabutylmmonium bromide to a dichloromethane solution of $\left[(\mathrm{CNC}) \mathrm{NiBr} \mathrm{PF}_{6}\right.$ 10. $\mathrm{PF}_{6}$ results in a significant change in the UV-vis spectra (Fig. 10). With subsequent additions of tetrabutylammonium bromide the intensity of the peaks at $c a .450$ and $540 \mathrm{~nm}$ increase and at the same time the intensity the peak at $c a .395 \mathrm{mn}$ slightly decreases. After the addition of excess bromide ( $>5$ equivalents) the spectrum is similar to that of solutions of the five-coordinate $\left[(\mathrm{CNC}) \mathrm{NiBr}_{2}\right]$ 9. In methanol solutions of $[(\mathrm{CNC}) \mathrm{NiBr}] \mathrm{PF}_{6} \mathbf{1 0} \cdot \mathrm{PF}_{6}$ there was no significant change in the spectra on the addition of tetrabutylammonium bromide. This solution behaviour is consistent with an equilibrium existing involving the four and five coordinate species (Scheme 2). It would 
appear that the ability of the solvent to solvate bromide ions is a major contributing factor as to the position of the equilibrium. The isosbestic point at $c a .420 \mathrm{~nm}$ in Fig. 10 is consistent with the equilibrium involving only two species that absorb in the visible spectrum, presumably $\left[(\mathrm{CNC}) \mathrm{NiBr}_{2}\right] \mathbf{9}$ and $[(\mathrm{CNC}) \mathrm{NiBr}]^{+} \mathbf{1 0}$. When solutions of $\mathbf{9}$ in dichloromethane were treated with increasing amounts of water (within solubility limits) the position of the equilibrium shifted away from the five-coordinate 9. This change in the equilibrium position was observed by the decrease of the absorbance peaks at $c a .450$ and $550 \mathrm{~nm}$ and an increase in the peak at $c a .390 \mathrm{~nm}$ (Fig. 11), and is consistent with the increased solvation of the free bromide by water.

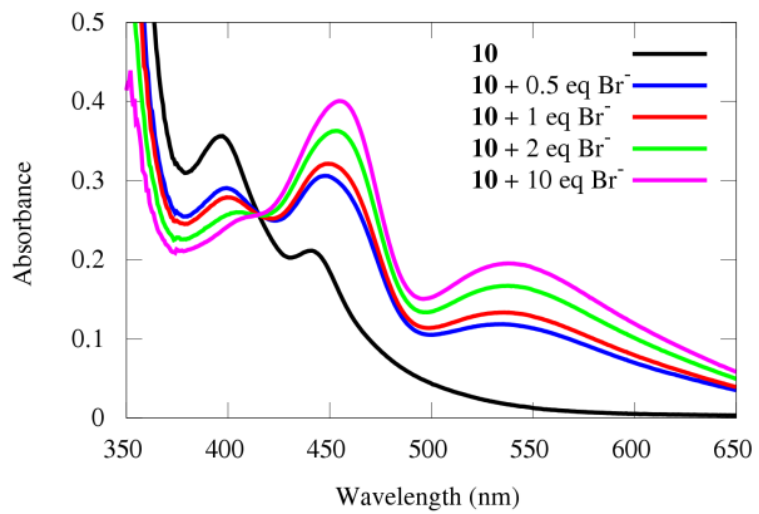

Fig. 10. UV-Vis spectra of a solution of $\mathbf{1 0} \cdot \mathrm{PF}_{6}$ in dichloromethane $\left(c a .10^{-4} \mathrm{M}\right)$ with successive additions of tetrabutylammonium bromide.

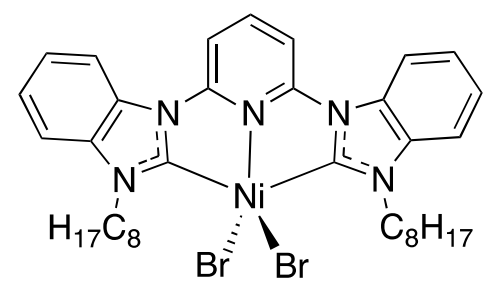

9

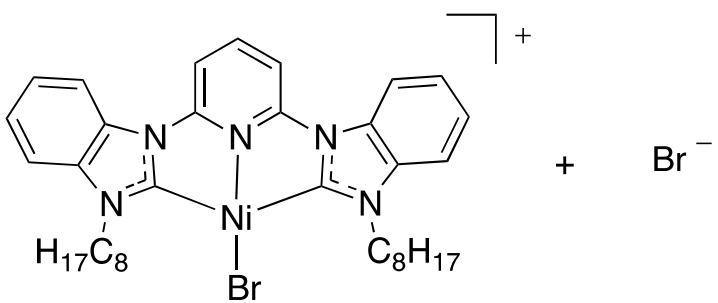

10

Scheme 2. Equilibria involving $\mathbf{9}$ and $\mathbf{1 0}$ in solution. 


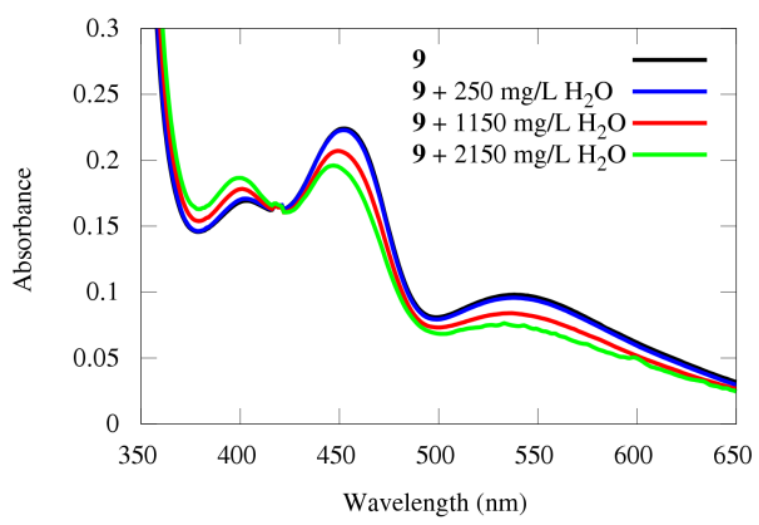

Fig. 11. UV-Vis spectra of a solution of 9 in dichloromethane $\left(c a .10^{-4} \mathrm{M}\right)$ with successive additions of water.

The methoxy-functionalised complex $\mathbf{6}$ appeared to behave differently in dichloromethane solutions compared to 9. The UV-vis spectra for dichloromethane solutions of $\mathbf{6}$ and $7 \cdot \mathrm{PF}_{6}$ are remarkably similar (Fig. 12). Although there is an increase in the absorbance at $c a .550 \mathrm{~nm}$ in the solution of 6 in dichloromethane, it is not as pronounced as the spectrum of 9 in dichloromethane. The addition of a large excess of tetrabutylammonium bromide to the solution of $\mathbf{6}$ in dichloromethane resulted in a small enhancement of the absorbance at $550 \mathrm{~nm}$ (Fig. 13). It would appear that in the case of 6 the addition of the methoxy-substituents causes the nickel to favour, though possible not exclusively, a four-coordinate geometry in solution. However in the solid-state the colour of $\mathbf{6}$ (dark purple) is consistent with the five-coordinate geometry. This may be a result of the subtle differences in the complex structure (see Solid-state studies) or as a result of an electronic influence of the methoxy groups on the carbene donor atoms. 


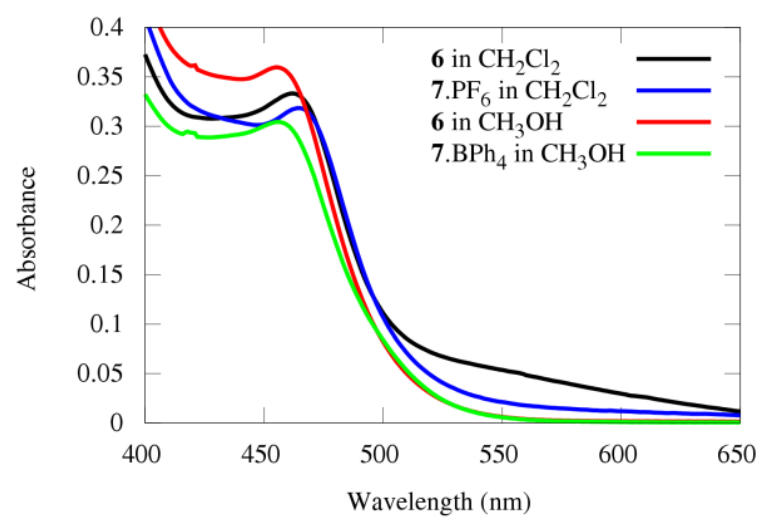

Fig. 12. UV-Vis spectra of 6 and $7\left(7 \cdot \mathrm{PF}_{6}, 7 \cdot \mathrm{BPh}_{4}\right)$ in dichloromethane and methanol solutions ( $c a$.

$$
\left.10^{-4} \mathrm{M}\right)
$$

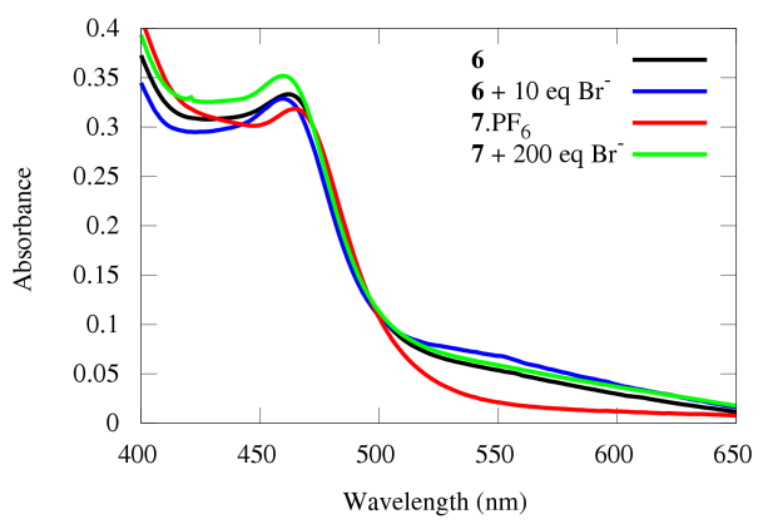

Fig. 13. UV-Vis spectra of solution of 6 and 7. $\mathrm{PF}_{6}$ in dichloromethane $\left(\mathrm{ca} \cdot 10^{-4} \mathrm{M}\right)$, with the addition of tetrabutylammonium bromide.

\section{Catalysis studies}

The catalytic activity of complexes 6 and $2(X=B r)$ were evaluated in Tamao-Kumada-Corriu coupling reactions against several aryl substrates of varying electronic and steric properties (Table 2). Despite the very low solubility of both complexes in THF, the addition of the Grignard reagent to the mixture afforded a dark red solution, presumably as a result of the dissolution of the complex. The results show that only moderate yields of coupling products were, with complex $2(\mathrm{X}=\mathrm{Br})$ proving to be the 'better' catalyst (Table 2). Both complexes show little tolerance for sterically 
hindered substrates. Significant homo-coupled products (from the Grignard reagents) were found in all reactions, which has been previously reported for similar systems. ${ }^{[26]}$ This side reaction is believed to be responsible for lower than expected yields as the Grignard reagent is consumed in the formation of the homocoupled product. The catalyst only showed reactivity towards aryl halides. The attempted coupling of alkyl halides [e.g. (4-bromobutoxy)benzene] did not form the desired product, instead ${ }^{1} \mathrm{H}$ NMR analysis indicated the formation of alkenes (e.g. 4-phenoxybut-1-ene), suggesting a $\beta$-hydride elimination pathway. Without the addition of the nickel complexes there was no reaction between (4-bromobutoxy)benzene and the Grignard. The more soluble complexes 7. $\mathrm{PF}_{6}$ and $3 \cdot \mathrm{PF}_{6}$ were also tested, and found to have similar activity to their parent compounds. In comparison to the imidazole-based analogue $\mathbf{1} \cdot \mathrm{Br}$ the benzimidazolin-2-ylidene pincer complexes studied here proved to be less efficient catalysts in Tamao-Kumada-Corriu coupling reactions. ${ }^{\text {[26] }}$ The complexes also displayed less activity than a benzimidazolin-2-ylidene nickel complex of the type $\left[(\mathrm{NHC})_{2} \mathrm{NiBr}_{2}\right]$ bearing a cis-chelating dibenzimidazolin-2-ylidene ligand. ${ }^{[27]}$ 
Table 2. Tamao-Kumada-Corriu coupling reactions catalyzed by complexes $\mathbf{6}$ and $\mathbf{2}(\mathrm{X}=\mathrm{Br}){ }^{\mathrm{a}}$

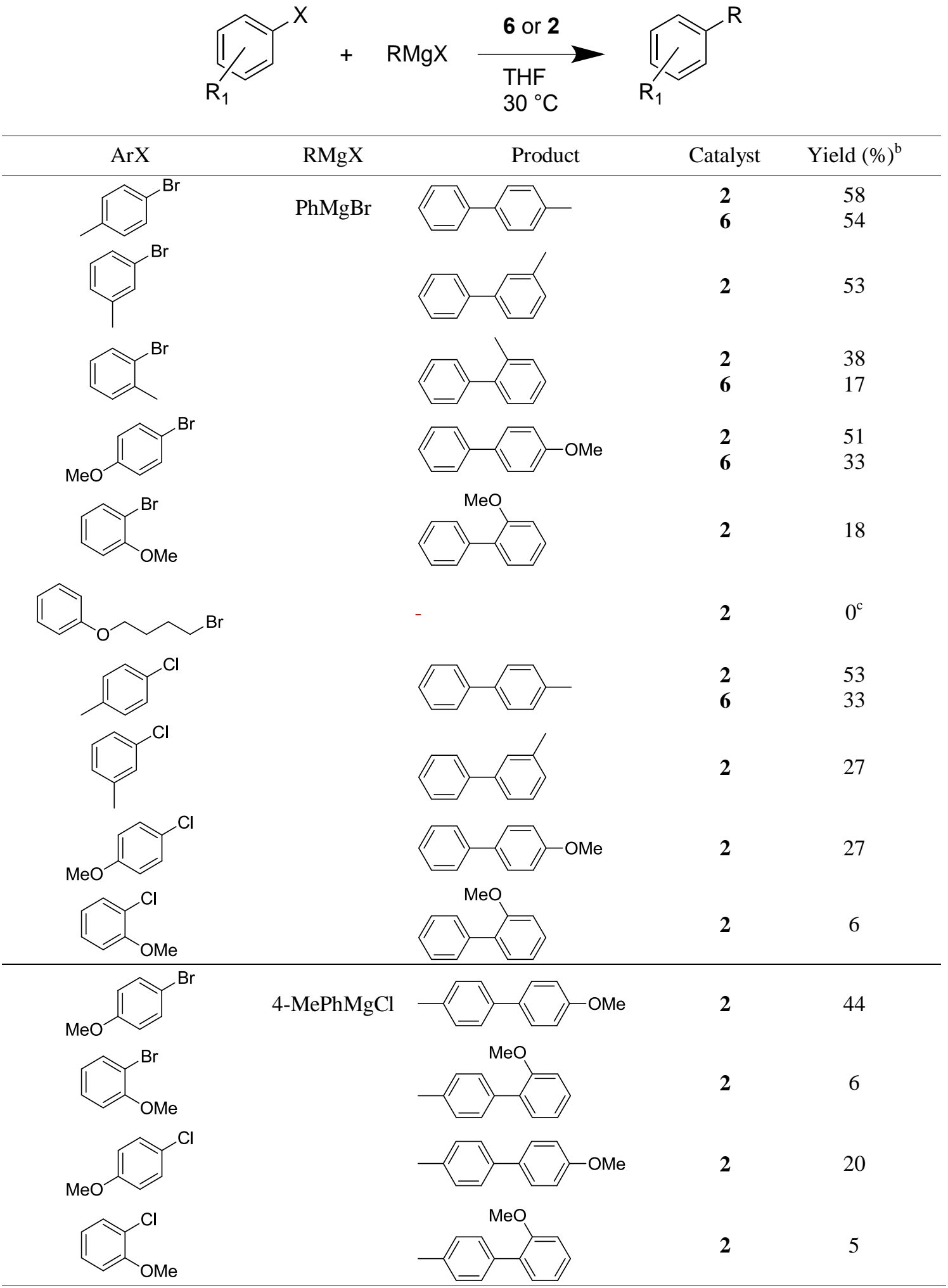

${ }^{a}$ Conditions: Aryl halide $(1.0 \mathrm{mmol}), \operatorname{ArMgX}(1.5 \mathrm{mmol})$ and catalyst $(0.05 \mathrm{mmol})$ in THF $(1.5 \mathrm{~mL}) ; 24$ $\mathrm{h}, 30^{\circ} \mathrm{C}$ under Ar. ${ }^{\text {b} Y i e l d ~ d e t e r m i n e d ~ b y ~ G C-F I D ~ u s i n g ~ b i s(e t h y l e n e g l y c o l) ~ d i b u t y l ~ e t h e r ~ a s ~ a n ~ i n t e r n a l ~}$ standard from an average of two runs. ${ }^{\mathrm{c}}$ Yield determined by ${ }^{1} \mathrm{H}$ NMR. 


\section{Conclusions}

Solution studies of the octyl-substituted bis(benzimidazolin-2-ylidene)pyridyl pincer fivecoordinate nickel complex $\left[(\mathrm{CNC}) \mathrm{NiBr}_{2}\right]$ suggests that the complex, with a five-coordinate geometry, can exist in solution, unlike what was observed in earlier studies. ${ }^{[13]}$ The five-coordinate species is in an equilibrium with the four-coordinate species $[(\mathrm{CNC}) \mathrm{NiBr}]^{+}$, and the equilibrium is strongly influenced by the nature of the solvent system, in addition to ligand variations (pincer and halide) as reported previously. ${ }^{[13]}$ The addition of methoxy groups to the periphery of the benzimidazolin-2-ylidene appears to result in the favouring of the 4-coordinate geometry in solution, though the exact reason for this preference is unknown. The nickel complexes displayed only moderate activity in Tamao-Kumada-Corriu coupling reactions.

\section{Experimental}

Nuclear magnetic resonance (NMR) spectra were recorded using a Bruker AV400N $(400.13 \mathrm{MHz}$ for ${ }^{1} \mathrm{H}, 100.61 \mathrm{MHz}$ for ${ }^{13} \mathrm{C}$ ) spectrometer at $300 \mathrm{~K} .{ }^{1} \mathrm{H}$ and ${ }^{13} \mathrm{C}$ chemical shifts were referenced to the residual solvent resonances. Assignments of NMR spectra were made with the aid of DEPT, ${ }^{1} \mathrm{H}-$ ${ }^{1} \mathrm{H}$ COSY, HSQC (one-bond ${ }^{1} \mathrm{H}_{-}{ }^{13} \mathrm{C}$ correlations) and $\mathrm{HMBC}$ (two- and three-bond ${ }^{1} \mathrm{H}_{-}{ }^{13} \mathrm{C}$ correlations) experiments. Coupling reactions were analysed using a HP 5890A gas chromatograph with a flame ionisation detector. Microanalyses were performed by the Central Science Laboratory, University of Tasmania, or locally using Perkin Elmer 2400 CHNS/O Analyser. UV-vis spectra were collected using Perkin-Elmer Lambda 35 or GBC 916 UV/vis spectrophotometers. Quoted peak maxima are for the range 350-700 nm. 5,6-Dimethoxybenzimidazole, ${ }^{[24]}$ 1,3-bis(benzimidazol1-yl)pyridine ${ }^{[10]}$ the five coordinate $\left[(\mathrm{CNC}) \mathrm{NiBr}_{2}\right]$ complex $2(\mathrm{X}=\mathrm{Br})^{[13]}$ and the 4 coordinate $[(\mathrm{CNC}) \mathrm{NiBr}] \mathrm{PF}_{6}$ salt $3 \cdot \mathrm{PF}_{6}(\mathrm{X}=\mathrm{Br})^{[13]}$ were synthesised by literature procedures. 


\section{1,3-Bis(5,6-dimethoxybenzimidazol-1-yl)pyridine (4)}

A solution of 5,6-dimethoxybenzimidazole $(2.0 \mathrm{~g}, 11 \mathrm{mmol})$ in dimethylformamide $(10 \mathrm{~mL})$ was added dropwise to a cooled (ice-bath) suspension of sodium hydride (60\% dispersion in oil, $0.50 \mathrm{~g}$, $12 \mathrm{mmol})$ in dimethylformamide $(10 \mathrm{~mL})$. The reaction mixture was warmed to room temperature and stirred for $1 \mathrm{~h}$ and then 2,6-dichloropyridine $(0.68 \mathrm{~g}, 4.6 \mathrm{mmol})$ was added. The resulting mixture was then heated at $70{ }^{\circ} \mathrm{C}$ for $24 \mathrm{~h}$, and then at $140{ }^{\circ} \mathrm{C}$ for a further $24 \mathrm{~h}$. The mixture was cooled and then diluted with water $(20 \mathrm{~mL})$. The resulting precipitation was collected, washed with diethyl ether $(2 \times 10 \mathrm{~mL})$ and recrystallised from toluene $(\sim 50 \mathrm{~mL})$ to produce a light pink powder $(1.62 \mathrm{~g}, 65 \%) . \delta_{\mathrm{H}}\left(\mathrm{CDCl}_{3}\right) 3.76\left(\mathrm{~s}, 6 \mathrm{H}, 2 \times \mathrm{OCH}_{3}\right), 3.97\left(\mathrm{~s}, 6 \mathrm{H}, 2 \times \mathrm{OCH}_{3}\right), 7.34(\mathrm{~s}, 2 \mathrm{H}, 2 \times$ benzimidazolyl $\mathrm{CH}), 7.50(\mathrm{~d}, J$ 8.0, 2H, $2 \times$ pyridyl $\mathrm{H} 3$ and $\mathrm{H} 5), 7.80(\mathrm{~s}, 2 \mathrm{H}, 2 \times$ benzimidazolyl $\mathrm{CH}) 8.11\left(\mathrm{t}, J 8.0,1 \mathrm{H}\right.$, pyridyl H4), $8.46(\mathrm{~s}, 2 \mathrm{H}, 2 \times$ benzimidazolyl $\mathrm{CH}) . \delta_{\mathrm{C}}\left(\mathrm{CDCl}_{3}\right) 56.3\left(\mathrm{OCH}_{3}\right)$, $56.3\left(\mathrm{OCH}_{3}\right), 96.7(\mathrm{CH}$, benzimidazolyl $\mathrm{C} 4$ or $\mathrm{C} 7), 102.4(\mathrm{CH}$, benzimidazolyl $\mathrm{C} 7$ or $\mathrm{C} 4), 110.3$ (CH, pyridyl C3/C5), 125.7 (C, benzimidazolyl C8 or C9), 138.3 (C, benzimidazolyl C9 or C8), 139.1 (benzimidazole C2), 141.9 (CH, pyridyl C4), 147.6 (C, benzimidazolyl C5 or C6), 148.2 (C, benzimidazolyl C6 or C5), 149.7 (C, pyridyl C2/C6). Anal. Calc. for $\mathrm{C}_{23} \mathrm{H}_{21} \mathrm{~N}_{5} \mathrm{O}_{4}$ : C 64.03, $\mathrm{H} 4.91$, N 16.23. Found C 63.99, H 4.78, N 16.08.

\section{1,1'-(2,6-Pyridyl)bis(3-n-butyl-5,6-dimethoxybenzimidazolium) dibromide (5-2Br)}

A mixture of 1-bromobutane $(5.0 \mathrm{~mL}, 29 \mathrm{mmol})$ and $4(0.84 \mathrm{~g}, 1.9 \mathrm{mmol})$ in dimethylformamide $(10 \mathrm{~mL})$ was sealed in a screw-capped flask and then heated at $100{ }^{\circ} \mathrm{C}$ for $48 \mathrm{~h}$. The mixture was cooled and a precipitate was collected. The filtrate was diluted with diethyl ether $(50 \mathrm{~mL})$ and the resulting precipitate collected. The solids were combined, and then recrystallised from 1-propanol $(\sim 10 \mathrm{~mL})$ to afford a colourless powder $(0.79 \mathrm{~g}, 57 \%) . \delta_{\mathrm{H}}\left(\mathrm{CDCl}_{3}\right) 1.04\left(\mathrm{t}, J 7.36 \mathrm{~Hz}, 6 \mathrm{H}, 2 \times \mathrm{CH}_{3}\right)$, $1.56\left(\mathrm{~m}, 4 \mathrm{H}, 2 \times \mathrm{CH}_{2}\right), 2.14\left(\mathrm{~m}, 4 \mathrm{H}, 2 \times \mathrm{CH}_{2}\right), 4.03\left(\mathrm{~s}, 6 \mathrm{H}, \mathrm{OCH}_{3}\right), 4.08\left(\mathrm{~s}, 6 \mathrm{H}, \mathrm{OCH}_{3}\right), 4.86(\mathrm{t}, J$ 7.34, 4H, $2 \times \mathrm{NCH}_{2}$ ), 7.17 (s, 2H, $2 \times$ benzimidazolyl $\mathrm{H} 4$ or $\mathrm{H} 7$ ), 7.93 (s, 2H, $2 \times$ benzimidazolyl H7 or H4), 8.45 (t, $J 8.10,1 \mathrm{H}$, pyridyl H4), 8.67 (d, $J 8.0,2 \mathrm{H}, 2 \times$ pyridyl H3 and H5), 11.88 (s, 
2H, NCHN). $\delta_{\mathrm{C}}\left(\mathrm{CDCl}_{3}\right) 13.6\left(\mathrm{CH}_{3}\right), 19.9\left(\mathrm{CH}_{2}\right), 31.4\left(\mathrm{CH}_{2}\right), 48.1\left(\mathrm{NCH}_{2}\right), 57.0\left(\mathrm{OCH}_{3}\right), 57.9$ $\left(\mathrm{OCH}_{3}\right), 94.7(\mathrm{CH}$, benzimidazolyl $\mathrm{C} 4$ or $\mathrm{C} 7), 97.3,(\mathrm{CH}$, benzimidazolyl $\mathrm{C} 7$ or $\mathrm{C} 4), 117.6(\mathrm{CH}$, pyridyl C3/C5), 123.5 (C, benzimidazolyl C8), 125.7 (C, benzimidazolyl C9), 139.7 (CH, benzimidazolyl C2), 146.1 (CH, pyridyl C4), 146.3 (C, pyridyl C2/C6), 150.1 (C, benzimidazolyl C6 or C5), 151.6 (C, benzimidazolyl C5 or C6). Anal. Calc. for $\mathrm{C}_{31} \mathrm{H}_{39} \mathrm{Br}_{2} \mathrm{~N}_{5} \mathrm{O}_{4} \cdot 0.6$ $\mathrm{CH}_{3} \mathrm{CH}_{2} \mathrm{CH}_{2} \mathrm{OH} \cdot 1.5 \mathrm{H}_{2} \mathrm{O}$ : C 51.26, H 6.14, N 9.11. Found C 51.44, H 5.92, N 8.99.

\section{1,1'-(2,6-Pyridyl)bis(3-n-octylbenzimidazolium) dibromide $(\mathbf{8} \cdot 2 \mathrm{Br})$}

A mixture of 1,3-bis(benzimidazol-1-yl)pyridine ( $8.0 \mathrm{~g}, 25 \mathrm{mmol})$ and 1-bromooctane (50 mL, 0.29 mol) in dimethylformamide $(70 \mathrm{~mL})$ was heated at $120{ }^{\circ} \mathrm{C}$ for $24 \mathrm{~h}$ and then at $140{ }^{\circ} \mathrm{C}$ for $48 \mathrm{~h}$. The reaction mixture was cooled and the resulting precipitate was collected and washed with diethyl ether $(2 \times 20 \mathrm{~mL})$ to afford a colourless powder $(11.4 \mathrm{~g}, 63 \%) . \delta_{\mathrm{H}}\left[\left(\mathrm{CD}_{3}\right)_{2} \mathrm{SO}\right] 0.86(\mathrm{~m}, 6 \mathrm{H}, 2 \times$ $\left.\mathrm{CH}_{3}\right), 1.27-1.47\left(\mathrm{~m}, 20 \mathrm{H}, 10 \times \mathrm{CH}_{2}\right), 2.07\left(\mathrm{~m}, 4 \mathrm{H}, 2 \times \mathrm{CH}_{2}\right), 4.70\left(\mathrm{t}, J 7.6,4 \mathrm{H}, 2 \times \mathrm{NCH}_{2}\right), 7.80(\mathrm{~m}$, 2H, benzimidazolyl $\mathrm{H} 5$ or $\mathrm{H} 6), 7.82(\mathrm{~m}, 2 \mathrm{H}$, benzimidazolyl $\mathrm{H} 6$ or $\mathrm{H} 5), 8.30$ (d, $J$ 8.0, 2H, benzimidazolyl $\mathrm{H} 4$ or $\mathrm{H} 7), 8.41$ (d, $J$ 8.0, 2H, benzimidazolyl $\mathrm{H} 7$ or $\mathrm{H} 4), 8.48$ (d, $J$ 8.4, $2 \mathrm{H}, 2 \times$ pyridyl $\mathrm{H} 3$ and $\mathrm{H} 5), 8.78(\mathrm{t}, J 8.0,1 \mathrm{H}$, pyridyl $\mathrm{H} 4), 10.90(\mathrm{~s}, 2 \mathrm{H}, \mathrm{NCHN}) . \delta_{\mathrm{C}}\left[\left(\mathrm{CD}_{3}\right)_{2} \mathrm{SO}\right] 13.9$ $\left(\mathrm{CH}_{3}\right), 22.0\left(\mathrm{CH}_{2}\right), 25.8\left(\mathrm{CH}_{2}\right), 28.5\left(2 \times \mathrm{CH}_{2}\right), 31.2\left(2 \times \mathrm{CH}_{2}\right), 47.4\left(\mathrm{NCH}_{2}\right), 114.3(\mathrm{CH}$, benzimidazolyl $\mathrm{C} 7$ or $\mathrm{C} 4), 115.7(\mathrm{CH}$, benzimidazolyl $\mathrm{C} 4$ or $\mathrm{C} 7), 117.9(\mathrm{CH}$, pyridyl C3/C5), 127.3 (CH, benzimidazolyl C5 or C6), 127.9 (CH, benzimidazolyl C6 or C5), 129.5 (C, benzimidazolyl C8 or C9), 131.6 (C, benzimidazolyl C9 or C8), 142.9 (CH, benzimidazolyl C2), 144.5 (CH, pyridyl C4), 146.4 (C, pyridyl C2/C6). Anal. Calc. for $\mathrm{C}_{35} \mathrm{H}_{47} \mathrm{Br}_{2} \mathrm{~N}_{5}$ : C 60.26, H 6.79, N 10.04. Found C 59.97, H 6.77, N 9.81.

Dibromido[1,1'-(2,6-pyridyl)bis(3-n-butyl-5,6-dimethoxybenzimidazolin-2-ylidene)]nickel(II) (6)

A mixture of nickel acetate tetrahydrate $(0.52 \mathrm{~g}, 2.1 \mathrm{mmol})$ and $5 \cdot 2 \mathrm{Br}(1.0 \mathrm{~g}, 1.4 \mathrm{mmol})$ in dimethylformamide $(4 \mathrm{~mL})$ was heated from room temperature to $110^{\circ} \mathrm{C}$ over the course of $c a .10$ 
min and then immediately allowed to cool. The resulting precipitate was collected, washed with diethyl ether $(10 \mathrm{~mL})$ and recrystallised from nitromethane $(c a .150 \mathrm{~mL})$ to yield a purple fine crystalline solid $(0.58 \mathrm{~g}, 54 \%) . \lambda_{\max } / \mathrm{nm}\left(\varepsilon / \mathrm{M}^{-1} \mathrm{~cm}^{-1}\right)\left[\mathrm{CH}_{2} \mathrm{Cl}_{2}\right] 462(3300) ;\left[\mathrm{CH}_{3} \mathrm{OH}\right] 455(3600) . \delta_{\mathrm{H}}$ $\left[\mathrm{CDCl}_{3}+1\right.$ drop $\left.\mathrm{CD}_{3} \mathrm{OD}\right] 0.97\left(\mathrm{t}, J 7.2,2 \times 6 \mathrm{H}, \mathrm{CH}_{3}\right), 1.48\left(\mathrm{~m}, 4 \mathrm{H}, 2 \times \mathrm{CH}_{2}\right), 1.85(\mathrm{~m}, 4 \mathrm{H}, 2 \times$ $\left.\mathrm{CH}_{2}\right), 3.92\left(\mathrm{~s}, 6 \mathrm{H}, \mathrm{OCH}_{3}\right), 4.11\left(\mathrm{~s}, 6 \mathrm{H}, \mathrm{OCH}_{3}\right), 4.80\left(\mathrm{t}, J 7.6,4 \mathrm{H}, 2 \times \mathrm{NCH}_{2}\right), 6.98(\mathrm{~s}, 2 \mathrm{H}$, benzimidazolyl $\mathrm{H} 4$ or $\mathrm{H} 7$ ), 7.62 (s, 2H, benzimidazolyl $\mathrm{H} 7$ or $\mathrm{H} 4), 8.23$ (d, $J$ 8.4, 2H, $2 \times$ pyridyl $\mathrm{H} 3$ and $\mathrm{H} 5), 8.72\left(\mathrm{t}, J 8.4,1 \mathrm{H}\right.$, pyridyl H4). $\delta_{\mathrm{C}}\left[\mathrm{CDCl}_{3}+1\right.$ drop $\left.\mathrm{CD}_{3} \mathrm{OD}\right] 13.8\left(\mathrm{CH}_{3}\right), 19.9\left(\mathrm{CH}_{2}\right)$, $32.4\left(\mathrm{CH}_{2}\right), 47.0\left(\mathrm{NCH}_{2}\right), 57.4\left(\mathrm{OCH}_{3}\right), 57.8\left(\mathrm{OCH}_{3}\right), 95.0(\mathrm{CH}$, benzimidazolyl $\mathrm{C} 4$ or $\mathrm{C} 7), 95.9$ (CH, benzimidazolyl C7 or C4), 108.9 (CH, pyridyl C3/C5), 122.4 (C, benzimidazolyl C8), 129.2 (C, benzimidazolyl C9), 147.7 (CH, pyridyl C4), 149.2 (C, benzimidazolyl C5 or C6) 149.7 (C, benzimidazolyl C6 or C5), 150.4 (C, pyridyl C2/C6) 166.4 (C, C-Ni). Anal. Calc. for $\mathrm{C}_{31} \mathrm{H}_{37} \mathrm{Br}_{2} \mathrm{~N}_{5} \mathrm{NiO}_{4} \cdot \mathrm{H}_{2} \mathrm{O}: \mathrm{C}$ 47.72, H 5.04, N 8.98. Found C 47.63, H 5.12, N, 8.99.

Bromido[1,1'-(2,6-pyridyl)bis(3-n-butyl-5,6-dimethoxybenzimidazolin-2-ylidene)]nickel(II) hexafluorophosphate $\left(7 \cdot P F_{6}\right)$

A mixture $6(0.11 \mathrm{~g}, 0.17 \mathrm{mmol})$ and potassium hexafluorophosphate $(60 \mathrm{mg}, 0.33 \mathrm{mmol})$ in methanol $(20 \mathrm{~mL})$ was warmed for $5 \mathrm{~min}$ until an orange precipitate developed. The solid was collected, washed with water $(5 \mathrm{~mL})$ and diethyl ether $(2 \times 10 \mathrm{~mL})$, and dried to afford an orange powder $(0.10 \mathrm{~g}, 85 \%) . \lambda_{\max } / \mathrm{nm}\left(\varepsilon / \mathrm{M}^{-1} \mathrm{~cm}^{-1}\right)\left[\mathrm{CH}_{2} \mathrm{Cl}_{2}\right] 464(3200) . \delta_{\mathrm{H}}\left[90 \% \mathrm{CDCl}_{3}, 10 \%\left(\mathrm{CD}_{3}\right)_{2} \mathrm{SO}\right]$ $0.95\left(\mathrm{t}, J\right.$ 7.2, $\left.6 \mathrm{H}, 2 \times \mathrm{CH}_{3}\right), 1.45\left(\mathrm{~m}, 4 \mathrm{H}, 2 \times \mathrm{CH}_{2}\right), 1.82\left(\mathrm{~m}, 4 \mathrm{H}, 2 \times \mathrm{CH}_{2}\right), 3.92\left(\mathrm{~s}, 6 \mathrm{H}, \mathrm{OCH}_{3}\right)$, $3.97\left(\mathrm{~s}, 6 \mathrm{H}, \mathrm{OCH}_{3}\right), 4.76\left(\mathrm{~m}, 4 \mathrm{H}, 2 \times \mathrm{NCH}_{2}\right), 7.04(\mathrm{~s}, 2 \mathrm{H}, 2 \times$ benzimidazolyl H4 or H7), 7.43 (s, 2H, $2 \times$ benzimidazolyl $\mathrm{H} 7$ or H4), $7.97(\mathrm{~d}, J 8.4,2 \mathrm{H}, 2 \times$ pyridyl $\mathrm{H} 3$ and $\mathrm{H} 5), 8.40(\mathrm{t}, J 8.4,1 \mathrm{H}$, pyridyl H4). $\delta_{\mathrm{C}}\left(90 \% \mathrm{CDCl}_{3}, 10 \%\left(\mathrm{CD}_{3}\right)_{2} \mathrm{SO}\right) 13.0\left(\mathrm{CH}_{3}\right), 18.8\left(\mathrm{CH}_{2}\right), 31.5\left(\mathrm{CH}_{2}\right), 45.9\left(\mathrm{CH}_{2}\right), 55.8$ $\left(\mathrm{OCH}_{3}\right), 56.2\left(\mathrm{OCH}_{3}\right), 94.2(\mathrm{CH}$, benzimidazolyl $\mathrm{C} 4$ or $\mathrm{C} 7), 94.6,(\mathrm{CH}$, benzimidazolyl $\mathrm{C} 7$ or $\mathrm{C} 4)$, 107.3 (CH, pyridyl C3/C5), 121.5 (C, benzimidazolyl C8 or C9), 128.6 (C, benzimidazolyl C9 or C8), 146.0 (CH, pyridyl C4), 148.4 (C, benzimidazolyl C5 or C6), 148.8 (C, benzimidazolyl C6 or 
C5), 150.1 (C, pyridyl C2/C6), 165.6 (C, C-Ni). Anal. Calc. for $\mathrm{C}_{31} \mathrm{H}_{37} \mathrm{BrN}_{5} \mathrm{NiO}_{4} \mathrm{PF}_{6} \cdot \mathrm{H}_{2} \mathrm{O}: \mathrm{C} 44.05$, H 4.65, N 8.29. Found C 44.04, H 4.61, N 8.26.

Bromido[1,1'-(2,6-pyridyl)bis(3-n-butyl-5,6-dimethoxybenzimidazolin-2-ylidene)]nickel(II) tetraphenylborate $\left(7 \cdot \mathrm{BPh}_{4}\right)$

A mixture of $6(0.15 \mathrm{~g}, 0.19 \mathrm{mmol})$ and sodium tetraphenylborate $(0.14 \mathrm{~g}, 0.40 \mathrm{mmol})$ in methanol $(10 \mathrm{~mL})$ was warmed for $5 \mathrm{~min}$. The mixture was then diluted with water $(10 \mathrm{~mL})$ and the resulting precipitate was collected. The solid was washed with water $(10 \mathrm{~mL})$ and methanol $(10 \mathrm{~mL})$ to afford an orange solid. The solid was recrystallised by the diffusion of vapours between a solution diethyl ether and a solution of the salt in dichloromethane to afford orange crystals $(0.14 \mathrm{~g}, 71 \%)$. $\lambda_{\max } / \mathrm{nm}\left(\varepsilon / \mathrm{M}^{-1} \mathrm{~cm}^{-1}\right)\left[\mathrm{CH}_{3} \mathrm{OH}\right] 456(3000) . \delta_{\mathrm{H}}\left(90 \% \mathrm{CDCl}_{3}, 10 \%\left(\mathrm{CD}_{3}\right)_{2} \mathrm{SO}\right) 0.90(\mathrm{t}, 6 \mathrm{H}, \mathrm{J} 7.2,2 \times$ $\mathrm{CH} 3), 1.41(\mathrm{~m}, 4 \mathrm{H}, \mathrm{CH} 2), 1.79\left(\mathrm{~m}, 4 \mathrm{H}, \mathrm{CH}_{2}\right), 3.82\left(\mathrm{~s}, 6 \mathrm{H}, \mathrm{OCH}_{3}\right), 3.86\left(\mathrm{~s}, 6 \mathrm{H}, \mathrm{OCH}_{3}\right), 4.72(\mathrm{t}, J$ 7.6, 4H, $\left.\mathrm{NCH}_{2}\right), 6.67\left(\mathrm{t}, 4 \mathrm{H}, J\right.$ 7.0, $\left.4 \times \mathrm{BPh}_{4} p-\mathrm{ArH}\right), 6.79-6.85\left(\mathrm{~m}, 10 \mathrm{H}, 8 \times \mathrm{BPh}_{4} m-\mathrm{ArH}, 2 \times\right.$ benzimidazolyl C4 or C7), 7.07 (s, 2H, $2 \times$ benzimidazolyl C4 or C7), 7.13 (d, J 8.3, 2H, pyridyl $\mathrm{H} 3$ and $\mathrm{H} 5), 7.23$ (br s, $\left.8 \mathrm{H}, 8 \times \mathrm{BPh}_{4} o-\mathrm{ArH}\right), 7.36$ (t, $J 8.2,1 \mathrm{H}$, pyridyl $\left.\mathrm{H} 4\right) . \delta_{C}\left(90 \% \mathrm{CDCl}_{3}, 10 \%\right.$ $\left.\left(\mathrm{CD}_{3}\right)_{2} \mathrm{SO}\right) 13.6\left(\mathrm{CH}_{3}\right), 19.6\left(\mathrm{CH}_{2}\right), 32.2\left(\mathrm{CH}_{2}\right), 46.7\left(\mathrm{CH}_{2}\right), 56.5\left(\mathrm{OCH}_{3}\right), 56.9\left(\mathrm{OCH}_{3}\right), 94.6(\mathrm{CH}$, benzimidazolyl $\mathrm{C} 4$ or $\mathrm{C} 7), 95.1(\mathrm{CH}$, benzimidazolyl $\mathrm{C} 7$ or $\mathrm{C} 4), 107.1(\mathrm{CH}$, pyridyl $\mathrm{C} 3 / \mathrm{C} 5), 121.5$ (CH, BPh 4 C4), 122.3 (C, benzimidazolyl C8), $125.4\left(\mathrm{CH}, \mathrm{BPh}_{4} \mathrm{C} 3 / \mathrm{C} 5\right), 129.3$ (C, benzimidazolyl C9), $135.8\left(\mathrm{CH}, \mathrm{BPh}_{4} \mathrm{C} 2 / \mathrm{C} 6\right), 146.7$ (CH, pyridyl C4), 149.2 (C, benzimidazolyl C5 or C6), 149.6 (benzimidazolyl C6 or C5), 150.6 (C, pyridyl C2/C6), 163.8 (C, q, J 49, $\mathrm{BPh}_{4}$ ipso-Ar) 166.6 (C, CNi). Anal. Calcd for $\mathrm{C}_{55} \mathrm{H}_{57} \mathrm{BBrN}_{5} \mathrm{NiO}_{4} ; \mathrm{C}, 65.96 ; \mathrm{H}, 5.74 ; \mathrm{N}, 6.99$. Found $\mathrm{C}, 66.26 ; \mathrm{H}, 5.72 ; \mathrm{N}$, 6.89. Crystals suitable for X-ray studies were grown by the diffusion of vapours between a solution diethyl ether and a solution of the salt in dichloromethane

Dibromido[1,1'-(2,6-pyridyl)bis(3-n-octylbenzimidazolin-2-ylidene)]nickel(II), [(CNC)NiBr 2$](\mathbf{9})$ 
A mixture of $8 \cdot 2 \mathrm{Br}(1.9 \mathrm{~g}, 2.8 \mathrm{mmol})$ and nickel acetate tetrahydrate $(0.88 \mathrm{~g}, 3.1 \mathrm{mmol})$ in dimethylsulfoxide $(11 \mathrm{~mL})$ was heated to $120{ }^{\circ} \mathrm{C}$ for $\mathrm{ca} .30 \mathrm{~min}$ and then allowed to cool. The mixture was diluted with diethyl ether $(20 \mathrm{~mL})$ and then stirred overnight. The resulting solid was collected and dried in vacuo to afford dark purple crystals $(2.5 \mathrm{~g}, 81 \%) . \lambda_{\max } / \mathrm{nm}\left(\varepsilon / \mathrm{M}^{-1} \mathrm{~cm}^{-1}\right)$ $\left[\mathrm{CH}_{2} \mathrm{Cl}_{2}\right] 538$ (1600), 453 (3700); $\left[\mathrm{CH}_{3} \mathrm{OH}\right] 434$ (2100), 392 (3500). $\delta_{\mathrm{H}}\left[\mathrm{CDCl}_{3}+1\right.$ drop $\left.\mathrm{CD}_{3} \mathrm{OD}\right]$ $0.90\left(\mathrm{~m}, 6 \mathrm{H}, 2 \times \mathrm{CH}_{3}\right), 1.25-1.37\left(\mathrm{~m}, 16 \mathrm{H}, 8 \times \mathrm{CH}_{2}\right), 1.61\left(\mathrm{~m}, 4 \mathrm{H}, 2 \times \mathrm{CH}_{2}\right), 2.10\left(\mathrm{~m}, 4 \mathrm{H}, 2 \times \mathrm{CH}_{2}\right)$, $4.82\left(\mathrm{~m}, 4 \mathrm{H}, 2 \mathrm{x} \mathrm{NCH}_{2}\right), 7.47-7.52(\mathrm{~m}, 4 \mathrm{H}$, benzimidazolyl $\mathrm{H} 5$ and $\left.\mathrm{H} 6)\right), 7.53(\mathrm{~m}, 2 \mathrm{H}$, benzimidazolyl $\mathrm{H} 7$ ), 7.87 (d, $J$ 8.4, 2H, $2 \times$ pyridyl $\mathrm{H} 3$ and $\mathrm{H} 5), 8.02$ (m, 2H, benzimidazolyl $\mathrm{H} 4$ ), $8.40\left(\mathrm{t}, J 8.4,1 \mathrm{H}\right.$, pyridyl H4). $\delta_{\mathrm{C}}\left[\mathrm{CDCl}_{3}+1\right.$ drop $\left.\mathrm{CD}_{3} \mathrm{OD}\right] 13.9\left(\mathrm{CH}_{3}\right), 22.5\left(\mathrm{CH}_{2}\right), 26.5\left(\mathrm{CH}_{2}\right)$, $29.1\left(\mathrm{CH}_{2}\right), 29.1\left(\mathrm{CH}_{2}\right), 30.0\left(\mathrm{CH}_{2}\right), 31.7\left(\mathrm{CH}_{2}\right), 47.8\left(\mathrm{NCH}_{2}\right), 108.0(\mathrm{CH}$, pyridyl C3/ C5), 112.2 $(\mathrm{CH}$, benzimidazolyl $\mathrm{C} 4$ or $\mathrm{C} 7), 112.5(\mathrm{CH}$, benzimidazolyl $\mathrm{C} 7$ or $\mathrm{C} 4), 125.9(\mathrm{CH}$, benzimidazolyl C5 or C6), 126.7 (CH, benzimidazolyl C6 or C5), 128.8 (C, benzimidazolyl C8), 135.6 (C, benzimidazolyl C9), 145.8 (CH, pyridyl C4), 150.6 (C, pyridyl C2/C6), 171.9 (C, C-Ni). Anal. Calc. for $\mathrm{C}_{35} \mathrm{H}_{45} \mathrm{Br}_{2} \mathrm{~N}_{5} \mathrm{Ni}$ : C 55.73, H 6.01, N 9.28. Found C 55.42, H 6.24, N, 9.11. Crystals suitable for X-ray studies were grown by the diffusion of vapours between a solution of THF and a solution of the complex in methanol.

Bromido[1,1'-(2,6-pyridyl)bis(3-n-octylbenzimidazolin-2-ylidene)]nickel(II) hexafluorophosphate, $[(C N C) N i B r] P F_{6}\left(10 \cdot P F_{6}\right)$

A mixture of $9(0.16 \mathrm{~g}, 0.22 \mathrm{mmol})$ and potassium hexafluorophosphate $(0.68 \mathrm{~g}, 3.7 \mathrm{mmol})$ in methanol $(10 \mathrm{~mL})$ was heated at reflux for $5 \mathrm{~min}$. Water $(9 \mathrm{~mL})$ was added and the mixture was heated for a further $5 \mathrm{~min}$. The reaction was allowed to cooled to RT, and then cooled in an ice bath. The resulting precipitate was collected, washed with methanol $(10 \mathrm{~mL})$ and water $(10 \mathrm{~mL})$, and dried to afford a yellow solid $(0.078 \mathrm{~g}, 43 \%) . \lambda_{\max } / \mathrm{nm}\left(\varepsilon / \mathrm{M}^{-1} \mathrm{~cm}^{-1}\right)\left[\mathrm{CH}_{2} \mathrm{Cl}_{2}\right] 432$ (1700), 387 (2900); $\left[\mathrm{CH}_{3} \mathrm{OH}\right] 440$ (1400), 394 (2400). $\delta_{\mathrm{H}}\left[90 \% \mathrm{CDCl}_{3}, 10 \%\left(\mathrm{CD}_{3}\right)_{2} \mathrm{SO}\right] 0.57\left(\mathrm{~m}, 6 \mathrm{H}, 2 \times \mathrm{CH}_{3}\right)$, 1.0-1.21 (m, 20H, $\left.10 \times \mathrm{CH}_{2}\right), 1.65\left(\mathrm{~m}, 4 \mathrm{H}, 2 \times \mathrm{CH}_{2}\right), 4.60\left(\mathrm{~m}, 4 \mathrm{H}, 2 \times \mathrm{NCH}_{2}\right), 7.26-7.34(\mathrm{~m}, 4 \mathrm{H}$, 
benzimidazolyl $\mathrm{H} 5$ and $\mathrm{H} 6), 7.38$ (d, $J$ 7.2, 2H, benzimidazolyl $\mathrm{H} 4$ or $\mathrm{H} 7), 7.73(\mathrm{~d}, J$ 8.0, $2 \mathrm{H}, 2 \times$ pyridyl $\mathrm{H} 3$ and $\mathrm{H} 5) 7.85(\mathrm{~d}, J 7.6,2 \mathrm{H}, \mathrm{H} 7$ or $\mathrm{H} 4), 8.20(\mathrm{t}, J 8.4,1 \mathrm{H}$, pyridyl $\mathrm{H} 4) . \delta_{\mathrm{C}}\left[90 \% \mathrm{CDCl}_{3}\right.$, $\left.10 \%\left(\mathrm{CD}_{3}\right)_{2} \mathrm{SO}\right] \delta 13.4\left(\mathrm{CH}_{3}\right), 21.6\left(\mathrm{CH}_{2}\right), 25.8\left(\mathrm{CH}_{2}\right), 27.4\left(\mathrm{CH}_{2}\right), 28.3\left(\mathrm{CH}_{2}\right), 29.6\left(\mathrm{CH}_{2}\right), 30.8$ $\left(\mathrm{CH}_{2}\right), 46.7\left(\mathrm{NCH}_{2}\right), 107.6(\mathrm{CH}$, pyridyl C3/C5), $111.8(\mathrm{CH}$, benzimidazolyl C4 or $\mathrm{C} 7), 111.9(\mathrm{CH}$, benzimidazolyl C7 or C4), $125.7(\mathrm{CH}$, benzimidazolyl $\mathrm{C} 5$ or $\mathrm{C6}), 126.3(\mathrm{CH}$, benzimidazolyl $\mathrm{C} 6$ or C5), 128.0 (C, benzimidazolyl C8), 135.0 (C, benzimidazolyl C9), 145.9 (CH, pyridyl C4), 150.4 (C, pyridyl C2/C6), 169.8 (C, C-Ni). Anal. Calc. for $\mathrm{C}_{35} \mathrm{H}_{45} \mathrm{BrN}_{5} \mathrm{NiPF}_{6}$ : C 51.31, H 5.54, N 8.55. Found C 51.55, H 5.36, N, 8.42.

\section{Catalysis studies}

Typical procedure for nickel catalysed Tamao-Kumada-Corriu coupling reaction: Grignard reagent (1.5 mL, $1 \mathrm{M}$ in tetrahydrofuran) was added to a mixture of aryl halide (1 mmol), nickel complex (5 mol\%, $0.05 \mathrm{mmol})$ and bis(ethyleneglycol) dibutyl ether $(45 \mathrm{mg})$ in an argon purged tube. The reaction was heated at $30{ }^{\circ} \mathrm{C}$ for $24 \mathrm{~h}$ in a Radleys parallel synthesizer. After cooling the reaction mixtures was quenched with $\mathrm{HCl}(2 \mathrm{~mL}, 1 \mathrm{M})$ and extracted with ethyl acetate $(2 \times 5 \mathrm{~mL})$ and dried with $\mathrm{CaCl}_{2}$. Product yields were determined by $\mathrm{GC}$.

\section{$X$-ray Structure Determinations}

The crystal data for $\mathbf{9}$ and $\mathbf{7} \cdot \mathrm{BPh}_{4} \cdot \mathrm{Et}_{2} \mathrm{O}$ are summarized below, with the structures depicted in Figures 1 and 2, where ellipsoids have been drawn at the 50\% probability level, and also in Figures 3-5. Selected coordination geometries are shown in Table 1. Crystallographic data for the structures were collected at 100(2) K on an Oxford Diffraction Xcalibur diffractometer (for 9) or an Oxford Diffraction Gemini diffractometer (for $\mathbf{7} \cdot \mathrm{BPh}_{4}$ ), both fitted with Mo K $\alpha$ radiation. Following analytical absorption corrections and solution by direct methods, the structures were refined against $F^{2}$ with full-matrix least-squares using the program SHELXL-97. ${ }^{[28]}$ Anisotropic displacement parameters were employed for the non-hydrogen atoms. All $\mathrm{H}$-atoms were added at calculated 
positions and refined by use of a riding model with isotropic displacement parameters based on those of the parent atom. Crystallographic data have been deposited with the Cambridge Crystallographic Data Centre (http://www.ccdc.cam.ac.uk), CCDC No. 862648 (9) and 862649 $\left(7 \cdot \mathrm{BPh}_{4} \cdot \mathrm{Et}_{2} \mathrm{O}\right)$.

Crystal data for 9: $\mathrm{C}_{35} \mathrm{H}_{45} \mathrm{Br}_{2} \mathrm{~N}_{5} \mathrm{Ni}, M=754.29$, triclinic, space group $P \overline{1}, a=9.6767(4), b=$ 12.7864(6), $c=13.9272(7) \AA ; \alpha=90.991(4), \beta=99.678(4), \gamma=102.541(4)^{\circ} ; V=1655.57(13) \AA^{3}$; $Z=2 ; D_{\mathrm{c}}=1.513 \mathrm{Mg} \mathrm{m}^{-3} ; \mu=3.032 \mathrm{~mm}^{-1}$; specimen: $0.26 \times 0.12 \times 0.02 \mathrm{~mm}^{3} ; \theta_{\max }=33.0^{\circ} ; 20784$ reflections collected; 11527 unique $\left(R_{\text {int }}=0.0338\right) ; T_{\max / \min }=0.95 / 0.65 ; G o F=1.085 ; R_{1}=0.0486$, $w R_{2}=0.0824[I>2 \sigma(I)]$

Crystal data for $7 \cdot \mathrm{BPh}_{4} \cdot \mathrm{Et}_{2} \mathrm{O}: \mathrm{C}_{59} \mathrm{H}_{67} \mathrm{BBrN}_{5} \mathrm{NiO}_{5}, M=1075.61$, triclinic, space group $P \overline{1}, a=$ 13.3548(4), $b=13.9625(4), c=17.3927(5) \AA ; \alpha=91.903(2), \beta=110.563(3), \gamma=117.055(3)^{\circ} ; V=$

$2630.82(18) \AA^{3} ; Z=2 ; D_{\mathrm{c}}=1.358 \mathrm{Mg} \mathrm{m}^{-3} ; \mu=1.183 \mathrm{~mm}^{-1}$; specimen: $0.52 \times 0.15 \times 0.12 \mathrm{~mm}^{3} ; \theta_{\max }$ $=35.0^{\circ} ; 63735$ reflections collected; 21593 unique $\left(R_{\text {int }}=0.0451\right) ; T_{\max / \min }=0.468 / 0.329 ; G o F=$ $0.903 ; R_{1}=0.0414, w R_{2}=0.0970[I>2 \sigma(I)]$.

\section{Supporting Information}

Images of $6,9,7 \cdot \mathrm{PF}_{6}$ and $\mathbf{1 0} \cdot \mathrm{PF}_{6}$ in the solid-state form are provided in Supporting Information.

\section{Acknowledgements}

We thank Curtin University for a Curtin University Research and Teaching Fellowship (to DHB), a Curtin University Internal Research Grant (to DHB) and a Curtin University Postgraduate Scholarship (to GT). The authors acknowledge the facilities, scientific and technical assistance of the Australian Microscopy \& Microanalysis Research Facility at the Centre for Microscopy, Characterisation \& Analysis, The University of Western Australia, a facility funded by the University, State and Commonwealth Governments. 


\section{References}

[1] D. Pugh, A. A. Danopoulos, Coord. Chem. Rev., 2007, 251, 610.

[2] M. Poyatos, J. A. Mata, E. Peris, Chem. Rev., 2009, 109, 3677.

[3] D. Yuan, H. Tang, L. Xiao, H. V. Huynh, Dalton Trans., 2011, 40, 8788.

[4] C. Y. Wong, L. M. Lai, P. K. Pat, L. H. Chung, Organometallics, 2010, 29, 2533.

[5] C.-S. Lee, S. Sabiah, J.-C. Wang, W.-S. Hwang, I. J. B. Lin, Organometallics, 2010, 29, 286.

[6] F. Jean-Baptiste dit Dominique, H. Gornitzka, A. Sournia-Saquet, C. Hemmert, Dalton Trans., 2009, 340.

[7] A. Mrutu, K. I. Goldberg, R. A. Kemp, Inorg. Chim. Acta, 2010, 364, 115.

[8] A. Mrutu, D. A. Dickie, K. I. Goldberg, R. A. Kemp, Inorg. Chem., 2011, 50, 2729.

[9] T. Tu, J. Malineni, K. H. Dötz, Adv. Synth. Catal., 2008, 350, 1791.

[10] D. H. Brown, G. L. Nealon, P. V. Simpson, B. W. Skelton, Z. Wang, Organometallics, 2009, 28, 1965.

[11] T. Tu, X. Bao, W. Assenmacher, H. Peterlik, J. Daniels, K. H. Dötz, Chem. Eur. J, 2009, 15, 1853.

[12] T. Tu, X. Feng, Z. Wang, X. Liu, Dalton Trans., 2010, 39, 10598.

[13] D. H. Brown, B. W. Skelton, Dalton Trans., 2011, 40, 8849.

[14] T. Tu, H. Mao, C. Herbert, M. Z. Xu, K. H. Dötz, Chem Commun, 2010, 46, 7796.

[15] K. Inamoto, J.-i. Kuroda, K. Hiroya, Y. Noda, M. Watanabe, T. Sakamoto, Organometallics, 2006, 25, 3095.

[16] K. Inamoto, J.-i. Kuroda, E. Kwon, K. Hiroya, T. Doi, J. Organomet. Chem., 2009, 694, 389.

[17] D. Pugh, A. Boyle, A. A. Danopoulos, Dalton Trans., 2008, 1087.

[18] M. V. Baker, D. H. Brown, P. V. Simpson, B. W. Skelton, A. H. White, Dalton Trans., 2009, 7294.

[19] M. V. Baker, D. H. Brown, P. V. Simpson, B. W. Skelton, A. H. White, Eur. J. Inorg. Chem., 2009, 1977.

[20] G. Zou, W. Huang, Y. Xiao, J. Tang, New J. Chem., 2006, 30, 803.

[21] P. V. Simpson, B. W. Skelton, D. H. Brown, M. V. Baker, Eur. J. Inorg. Chem., 2011, 1937.

[22] J. Nasielski, N. Hadei, G. Achonduh, E. A. B. Kantchev, C. J. O'Brien, A. Lough, M. G. Organ, Chem. Eur. J., 2010, 16, 10844.

[23] N. Hadei, E. A. B. Kantchev, C. J. O'Brien, M. G. Organ, Org. Lett., 2005, 7, 1991.

[24] D. T. Rosa, R. A. Reynolds III, S. M. Malinak, D. Coucouvanis, Inorg. Synth., 2002, 33, 112.

[25] J. A. Loch, M. Albrecht, E. Peris, J. Mata, J. W. Faller, R. H. Crabtree, Organometallics, 2002, 21, 700 .

[26] K. Inamoto, J.-i. Kuroda, T. Sakamoto, K. Hiroya, Synthesis, 2007, 2007, 2853.

[27] H. V. Huynh, R. Jothibasu, Eur. J. Inorg. Chem., 2009, 1926.

[28] G. M. Sheldrick, Acta Crystallogr., Sect. A, 2008, 64, 112. 